Original Articles

\title{
Ecosystem services as a resilience descriptor in habitat risk assessment using the InVEST model
}

\author{
Claudia Caro $^{\mathrm{a}, \mathrm{b}, *}$, João Carlos Marques ${ }^{\mathrm{a}}$, Pedro P. Cunha ${ }^{\mathrm{c}}$, Zara Teixeira ${ }^{\mathrm{a}}$ \\ ${ }^{a}$ University of Coimbra, MARE - Marine and Environmental Sciences Centre, Department of Life Sciences, 3000-456 Coimbra, Portugal \\ ${ }^{\mathrm{b}}$ Biology Department, Faculty of Sciences, La Molina National Agrarian University, Peru \\ ${ }^{\mathrm{c}}$ University of Coimbra, MARE - Marine and Environmental Sciences Centre, Department of Earth Sciences, Portugal
}

\section{A R T I C L E I N F O}

\section{Keywords:}

Ecosystem services abundance

Vulnerability

EUNIS habitats

Management

Wetlands

Mondego estuary

Portugal

\begin{abstract}
A B S T R A C T
Vulnerability of coastal ecosystems has been increasing as a result of human perturbations that compromise the ability to provide multiple ecosystem services. Vulnerability is a function of exposure to stressors and of sensitivity to impact and resilience; it has been suggested as a proxy of a habitat's ability to deliver ecosystem services. Different approaches have been proposed; some assume that vulnerability is lower when habitats provide more ecosystem services, as it increases the ecosystem adaptive capacity, while others assume the opposite, as multiple activities (exploiting multiple services) introduce multiple pressures. To establish a relationship between impact risk and ecosystem service supply potential, while accounting for these two apparently conflicting assumptions, it has been proposed adding ecosystem services' abundance as a resilience descriptor to the habitat risk assessment (HRA) model from the InVEST tool, assigning different weights to provisioning, regulation and cultural services. This study: (i) applies the modified HRA model (HRA_ES-2) to 21 habitats in an Atlantic coastal region; (ii) compares the results with a non-modified HRA model (HRA-1) and with other previous approaches; (iii) and explores management scenarios that could be translated into better environmental conditions for seagrass and saltmarsh habitats and, consequently, into positive impacts in the supply of ecosystem services by these habitats.

Results show that there are significant statistical differences between the HRA-1 model and the HRA_ES-2 model, and between the HRA_ES-2 model and approaches from other authors that also take ES into consideration. In addition, the cumulative risk obtained from the modified HRA_ES-2 model seems to be more in accordance with the social-environmental realm than the risk scores obtained with the HRA-1 model. Finally, the new model approach indicates that avoiding the degradation of saltmarsh and seagrass habitats will be possible with management measures acting upon the two stressors most contributing to habitat risk: sea level changes and organic enrichment due to nitrogen increase.

With this approach the user is able to account not only for the resilience of ecosystems that arises from the presence of ecosystem services, but also for the sensitivity associated to the potential impacts if ecosystem services are in demand, in a spatial explicit manner, which is an advantage compared to other approaches. The resilience component from the InVEST/HRA model is thus flexible to accommodate other variables than those proposed by the developers.
\end{abstract}

\section{Introduction}

Marine and coastal aquatic habitats are amongst the most productive ecosystems around the world, contributing with around $43 \%$ of total benefits provided by the biosphere to human well-being (Levrel et al., 2014), or in other words, contributing with a large percentage of ecosystem services. Unfortunately, multiple increasing human perturbations have been felt in these habitats (e.g. Barbier et al., 2011; Rao et al., 2015), such as biological and sedimentary resources exploitation (Islam and Haque, 2004), pollution (e.g. Santos and Andrade, 2009) and anthropization of natural areas, which may compromise the ability to provide provisioning, regulating and cultural services (Muñoz et al., 2018), including food, flood protection, natural environmental conservation and recreation activities. As a result, the vulnerability of

\footnotetext{
* Corresponding author at: University of Coimbra, MARE - Marine and Environmental Sciences Centre, Department of Life Sciences, Calçada Martim de Freitas, 3000-456 Coimbra, Portugal.

E-mail address: ccaro@lamolina.edu.pe (C. Caro).
} 
marine/coastal aquatic ecosystems has been increasing (Schröter et al., 2005; Cabral et al., 2015). It is widely accepted, however, that ecosystem vulnerability is not only a function of exposure to stressful uses and pressures, but also a function of impact, measured by sensitivity and adaptive capacity (Arkema et al., 2014; Cabral et al., 2015; Halpern et al., 2015). Sensitivity is the degree to which a human-environment system is affected by environmental change (Cabral et al., 2015); whereas adaptive capacity, or in other words, resilience, is the capacity of an ecosystem to absorb shocks and still maintain function (Folke, 2006).

In an exposure-impact approach to habitat risk assessment, vulnerability is linked to risk (Culhane et al., 2019), i.e., to the exposure to hazards, and has been suggested as a proxy of a habitat's ability, or potential, to deliver ecosystem services (ES) (Cabral et al., 2015). This perspective allows exploring the effects of ecosystem state changes in the supply of ecosystem services, but different approaches have been implemented. Cabral et al. (2015) assume that vulnerability is lower when habitats provide more ecosystem services, as it increases the ecosystem adaptive capacity. Others have also proposed that the capacity of habitats to deliver a large abundance of ecosystem services could be an expression of resilience to the natural variations of their environment (Brock et al., 2018; Arnan et al., 2019). However, Culhane et al. (2019) and Willaert et al. (2019) assume that vulnerability, and inherently impact risk, is more likely to increase with greater potential to supply ecosystem services, as "multiple activities (exploiting multiple services) introduce multiple pressures" (Culhane et al., 2019). These two contrasting assumptions seem counter-intuitive, but it could be argued that their coexistence is possible. Consider, as an example, two equivalent ecosystems with the same pressures. The one with the highest availability of ecosystem services will, in theory, be less vulnerable as it may have a higher capacity to self-organize and retain essentially the same function, structure, identity, and feedbacks, as well as the capacity to adapt to new conditions (Carpenter et al., 2001; Walker et al., 2004; Biggs et al., 2012). Likewise, when considering two habitats with the same ecosystem services, the one suffering the highest pressure as a result of ecosystem services demand will tend to be more vulnerable. In this context, habitats dominated by regulation services are expected to show less vulnerability and lower risk, as they do not require active exploitation (Culhane et al., 2019). Including the abundance of ecosystem services in the habitat risk assessment, highlights the importance of ecosystem services as endpoints in the decision making process (Munns et al., 2015), raising the interest of end-users in order to avoid the loss of habitats that deliver multiple services (Rodríguez-Loinaz et al., 2014), usually subject to multiple stressors (Willaert et al., 2019).

This study aims to find a suitable methodology to establish a relationship between impact risk and ecosystem service supply potential, while accounting for the two apparently conflicting assumptions abovementioned. Such methodology would greatly improve the ecosystembased management (EBM) of fully marine and coastal regions (Borja et al., 2016), which is clearly endorsed by the Marine Strategy Framework Directive (MSFD; EC, 2008), which "aims to achieve Good Environmental Status (GES) of the EU's marine waters by 2020 and to protect the resource base upon which marine-related economic and social activities depend". To achieve the main goal of this study, a set of three hypotheses have been developed, which also demonstrate the usefulness of combining habitat risk assessment with an ecosystem services approach and spatial planning (Arkema et al., 2015). All three hypotheses rely on a modified habitat risk assessment (HRA) model from the InVEST tool (Sharp et al., 2018), in which ecosystem services abundance is added as a resilience descriptor, introducing a novel approach that deviates from the vision introduced by the current InVEST/ HRA which expects four habitat-specific measures of resilience: natural mortality rate, recruitment rate, age at maturity and connectivity. Below are the three hypotheses to be tested:

H1: Adding ES abundance as a resilience descriptor will introduce significant and meaningful changes in the InVEST/HRA risk scores, compared to a model without resilience descriptors.

H2: A HRA model that accounts for ES abundance as an expression of environmental resilience and, at the same time, as a source of environmental stress due to demand, originates habitat risk values significantly different from other approaches that only take one of the assumptions into consideration.

H3: Improving the management effectiveness score of the stressors that most contribute for habitats' risk, will decrease the risk score of a modified HRA model.

The Atlantic coastal region adjacent to the Mondego River mouth (western central mainland Portugal; westernmost sector of the Iberian Peninsula) was used as a case study and scenarios were built to test the potential effect of management improvements that could be translated into better environmental conditions for seagrass and saltmarsh' habitats. This study case was selected because it is under a long-term monitoring program (Marques et al., 2007; Veríssimo et al., 2017), providing a suitable amount of data regarding pressures and their effects on ecosystems (e.g., Marques et al., 1993; Veríssimo et al., 2013a; Couto et al., 2014), which enables the assignment of magnitudes of pressures on habitats, the base of any habitat risk assessment procedure (Duggan et al., 2015). Seagrass and saltmarsh' habitats were selected for the development of future management scenarios due to their importance for local environmental quality and economic development. These habitats act as nursery areas to many species, some with commercial importance (Lillebø et al., 1999), show high carbon sequestration rates (Couto et al., 2013, 2014), contribute with nutrient fixation (Cardoso et al., 2004; Sousa et al., 2008), are efficient in the sedimentation function (promote the deposition of fine particles), buffering the sea level raise effects (Raposa et al., 2016) and reducing the erosion rate (Schoutens et al., 2019), and provide strong cultural benefits (Cullen-Unsworth et al., 2014). Moreover, during the last 25 years, seagrasses in the Mondego estuary have suffered high environmental fluctuations, led mainly by nutrient discharges coupled with hydromorphological changes determined by anthropic actions, which have significantly reduced the natural diversity of the study area (Dinis and Cunha, 1998; Neto et al., 2010; Veríssimo et al., 2013b). After 1997, when experimental mitigation measures were implemented, the water quality improved significantly with positive impacts on the environmental conditions (Neto et al., 2010). This work is thus assuming that the current stressors that might affect these habitats are different and should be assessed as well as their potential risk to these habitats.

\section{Methodology}

The methodology is oriented towards testing the three hypotheses defined in the Introduction section, using the Atlantic coastal region adjacent to the Mondego River as case study (Fig. 1).

\subsection{The study area}

The study area is the Atlantic coastal region adjacent to the Mondego River, located in the central western coast of mainland Portugal (Fig. 1). Two subareas are considered, based on water bodies defined under the scope of the Water Framework Directive (WFD) (Gonçalves et al. 2011; WFD; EC, 2000; Ferreira et al., 2006): a) transitional waters, corresponding to the lower and middle sectors of the estuary, which includes four transitional water bodies (here referred as WB1, WB2, WB-HMWB and WB3), and b) coastal waters, corresponding to the adjacent littoral and near part of the marine platform, which includes one coastal water body (CWB-1-3).

The study area has a semidiurnal regime and a tidal variation between 0.35 and $3.80 \mathrm{~m}$ and high energy wave hydrodynamics mostly between October to March. Wave direction is generally from West and Northwest with some occurrences from Southwest; wave periods are between 8 and $12 \mathrm{~s}$, with wave heights usually between 1 and $3 \mathrm{~m}$ that 

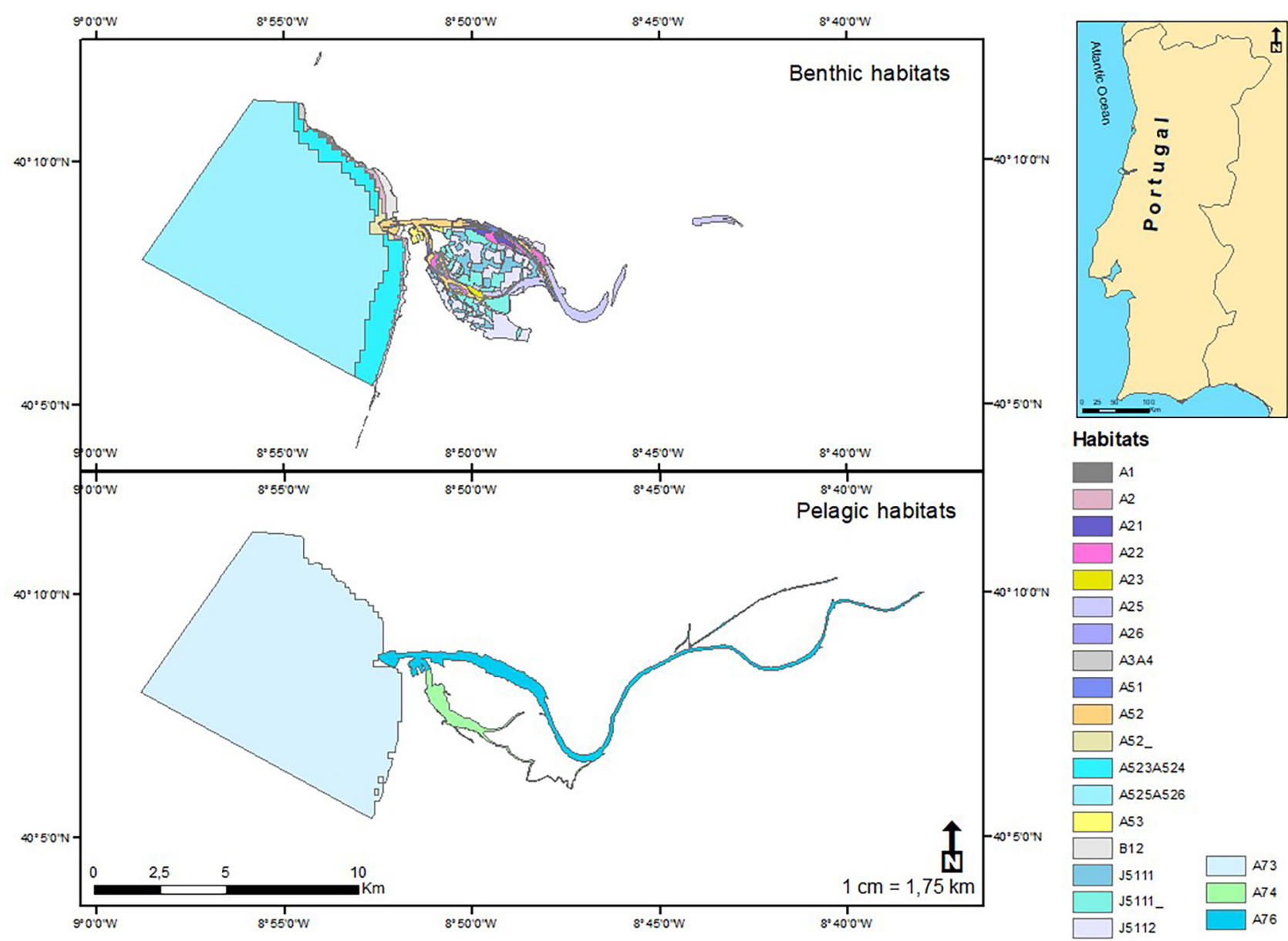

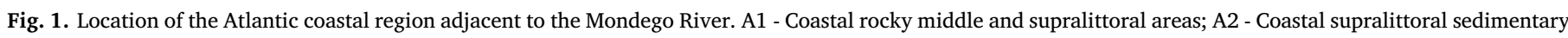

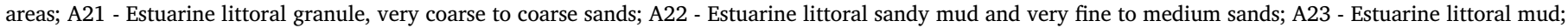

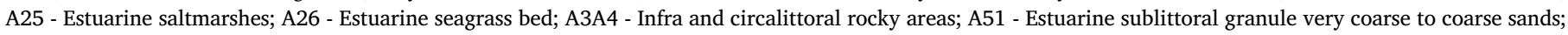

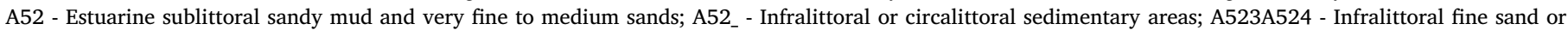

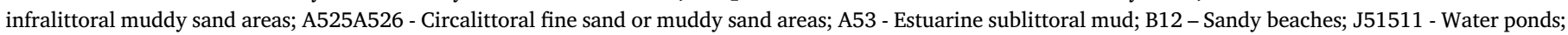

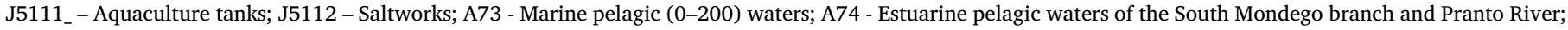
A76 - Estuarine pelagic waters of the North branch of the Mondego River and upstream system.

can reach up to $8 \mathrm{~m}$ in stormy conditions (Bettencourt et al., 2004). The coastline is dominated by sandy beaches that, at south of the river mouth, pass inland to an aeolian dune field and to the estuary (Cunha et al., 2006). The Mondego River mouth is adjacent to the town of Figueira da Foz.

The transitional waters conform a mesotidal well-mixed to partially mixed estuary, except during floods and droughts, being the two estuary subsystems quite different (Cunha, 2002). Being $21 \mathrm{~km}$ long and with a surface area of 860 ha, it has an irregular river discharge (Bettencourt et al., 2004), with a mean value of $79 \mathrm{~m}^{3} / \mathrm{s}$ of water from the Mondego River (Falcão et al., 2012; Teixeira et al., 2008). The last $7 \mathrm{~km}$ close to the estuary mouth are divided into two subsystems separated by the Morraceira Island. The Mondego subsystem (comprising the North branch and reaching Montemor-o-Velho, that is located c. $26 \mathrm{~km}$ upstream of the river mouth) is deeper (4-10 m during high tide), with strong salinity changes and comprising a bed load of medium to coarse sands (Marques et al., 1993; Cunha, 2002). The Pranto subsystem (South branch) is shallower (2-4 m during high tide), with frequent changes in temperature (Flindt et al., 1997), salinity (Cunha, 2002), but also presence of organic enrichment as a result of the Pranto River water inputs (Baeta et al., 2011) and aquaculture discharges.
Biophysical gradients along the Mondego transitional and coastal waters have originated a total of 21 habitats, where saltmarshes, seagrasses, sandy beaches, marine sedimentary areas, and marine rocky areas are dominant (Gaspar et al., 2017; Caro et al., 2020). All these habitats evidence great capacity to offer services such as water provision, eco-tourism opportunities, biological nursery grounds, food production and carbon storage (e.g., Pinto et al., 2014). Among the habitats of the Atlantic coastal region adjacent to the Mondego River, seagrass and saltmarsh ecosystems are among the most important. Seagrasses and saltmarshes play a vital role in the accretion of fine sediment and filtration of nutrients (Lillebø et al., 1999; Sousa et al., 2008), as nurseries, and supporting commercially important fisheries (Castro et al., 2016, 2019). With the ongoing climate change trend, the biomass of seagrass and saltmarsh species is expected to increase, fostered by high levels of $\mathrm{CO}^{2}$ in the atmosphere (Short et al., 2016) and an increment in the temperature (Couto et al., 2014). As result of sea level rise induced by global warming (IPCC, Intergovernmental Panel on Climate Change, 2018), the area occupied by these habitats is expected to diminish because the sedimentation rate of some species will presumably not be able to keep pace with increases in sea level (Couto et al., 2014; Raposa et al., 2016) and because the lateral migration inland is not allowed due to progressive urbanization towards the 
estuary area (Cunha et al., 1997).

Despite the social benefits that have been obtained from the Atlantic coastal region adjacent to the Mondego River, its present ecosystem services are in danger as a result of multiple pressures from natural and human origin (Teixeira et al., 2014), such as water flow control, through a series of dams and channels (Mantas et al., 2013), water extraction for irrigation projects (Pinto et al., 2013a), organic enrichment from nitrogen and phosphorus (Flindt et al., 1997, Teixeira and Marques, 2016), landfills and dredging/sand extraction (Cunha et al., 1998, 2006), fisheries (Pinto et al., 2013a), contaminants and marine litter inputs (Bessa et al., 2018; Botelho et al., 2019), presence of invasive species (Franco et al., 2012), sea level rise (Loureiro et al., 2017) and impacts from navigation and harbor activities, such as noise and contaminants (Ceia et al., 2013; Mantas et al., 2013).

To overcome challenges posed by the impacts in the study area, a diversity of social responses have been proposed, some focused on management measures and others focused on improving scientific knowledge about the system. Responses focused on management include a) the increase of the Pranto subsystem (South branch) hydrodynamics, through the reconnection of the upstream communication between this subsystem and the Mondego subsystem (North branch), with the consequent improvement of the environmental quality in the Pranto subsystem (Cunha, 2002; Veríssimo et al., 2013b); b) spatial planning of aquaculture and salt production activities to minimize the negative impacts on water quality, while reducing competition for space (Teixeira et al., 2018); and c) the definition of socio-economic scenarios to forecast the ecological impacts in the system, as a tool for decision-making (Pinto et al., 2013a). Responses focused on improving scientific knowledge include: a) the development of long-term datasets (around 30 years) through regular monitoring programs in the Mondego estuary, which are a crucial baseline to guide decision making (Pinto et al., 2014; Veríssimo et al., 2017); and b) the development of tools to report the estuary environmental quality status (Mantas et al., 2016; Neto et al., 2013).

\subsection{Testing hypothesis 1}

To test whether adding ES abundance as a resilience descriptor will introduce significant and meaningful changes in the InVEST/HRA risk scores, compared to a model without resilience descriptors (Hypothesis 1), two InVEST Habitat Risk Assessment models (HRA) were performed: (1) the HRA-1 model, which was calculated with no adaptations (see section2.2.1 for details); and (2) the HRA_ES-2 model, a modified version of the HRA-1 model, in which the ecosystem services' abundance was added as a resilience descriptor (see section 2.2.2 for details). Then, both models were cross-compared (see section 2.2.3 for details).

\subsubsection{The non-modified InVEST habitat risk assessment model (HRA-1)}

The InVEST Habitat Risk Assessment (HRA) model is an exposureconsequence framework that allows users to assess the cumulative risk posed to habitats affected by stressors, typically due to human activities, and to explore the consequences for the delivery of ecosystem services (Duggan et al., 2015; Sharp et al., 2018). When coupled with an Overlap Analysis model it allows the assessment of locations where stressors are having an impact on habitats (Wyatt et al., 2017).

The model assumes that the further the habitat is from the stressor, or exposure (E), the less the consequence (C) on it would be. This association follows a model decay that is linear when is applied to environmental studies (Ban et al., 2010). Exposure and consequence are both determined by assigning a rating (typically $1-3$, with $0=$ no score) to a set of criteria for each attribute (Table 1). For this study, scores were assigned to criteria based on information from peer-reviewed literature and expert judgement from researchers of the University of Coimbra with at least five years of research experience in the study area. Data model inputs include spatial explicit data of habitats, stressors and ecosystem services' abundance. In total, 18 benthic habitats, 3 pelagic habitats (Fig. 1), 13 stressors (Fig. 2) and 231 ecosystem services (Appendix A - Supplementary data) were analyzed. The criteria scores and the data model inputs are fully described in the supplementary material (Appendix A - Supplementary data).

The overall exposure $E$ (Eq. (1)) and consequence $C$ (Eq. (2)) scores are calculated as weighted averages of the exposure values $e_{i}$ and consequence values $c_{i}$ for each criterion $i$, from habitat $j$ and stressor $k$.

$E j k l=\frac{\sum_{i=1}^{N} \frac{e i j k l}{d i j k l * w i j k l}}{\sum_{i=1}^{N} \frac{1}{d i j k l * w i j k l}}$

$C j k l=\frac{\sum_{i=1}^{N} \frac{c i j k l}{d i j k l * w i j k l}}{\sum_{i=1}^{N} \frac{1}{d i j k l * w i j k l}}$

where $E j k l$ is the exposure score specific to habitat $j$, from stressor $k$ in location $l ; C j k l$ is the consequence score, eijkl is the exposure rating criterion $i$, specific to habitat $j$ and stressor $k$ and location $l$; cijkl is the consequence rating. dijkl represents the data quality rating, wijkl represents the importance weighing for criterion. $N$ is the number of criteria evaluated for each habitat.

The model also allows assigning weights to score according to data quality and importance of each criterion (Table 2).

After calculating the exposure and consequence scores, their values are combined to produce a risk value for each stressor-habitat combination in each grid cell. For the purpose of this work, risk calculation was based on the Euclidean distance from the origin in the exposureconsequence space (Arkema et al., 2014), where average exposure $(E j k l)$ is on one axis and the average consequence score $(C j k l)$ is on the other (Eq. (3) (Sharp et al., 2018).

$R j k l=\sqrt{(E j k l-1)^{2}+(C j k l-1)^{2}}$

where $R j k l$ is the risk to habitat $j$ caused by stressor $k$ in each location (i.e. cell).

The model then quantifies, in each location, the cumulative risk to each habitat from all stressors (Eq. (4), after which identifies areas of habitats that are risk 'hotspots'.

$R j l=\sum_{k=1}^{K} R j k l$

where $R j l$ is the sum of all risk scores by habitat $j$.

Risk 'hotspots' are further identified classifying grid cells as high, medium and low risk, based on the maximum risk score or on the total possible cumulative risk. For this study, the maximum risk score was applied, which assumes that when a stressor is particularly destructive, additional stressors will not further increase the risk of habitat degradation (Sharp et al., 2018). Using the Euclidean risk calculation and a score rank on a scale 1-3, the maximum risk score for an individual habitat-stressor combination is equal to 2.83 (Sharp et al., 2018). As such, high risk corresponds to grid cells with scores greater than 1.87 ( $66 \%$ of 2.83 ); medium risk corresponds to grid cells with scores between 0.93 and 1.86 (between $33 \%$ and $66 \%$ of 2.83); and low risk corresponds to grid cells with scores between 0.00 and 0.92 (between 0 and $33 \%)$.

To overcome habitats co-occurrence, the HRA model also provides an integrative index of risk across all habitats, i.e. an ecosystem risk, summing each habitat risk scores in a cell, which represents the total risk output of the model. Ecosystem risk increases with an increasing number of co-occurring habitats (Eq. (5)).

$R l=\sum_{j=1}^{J} R j l$

Where $R l$ is the sum of risk scores across all habitats. 


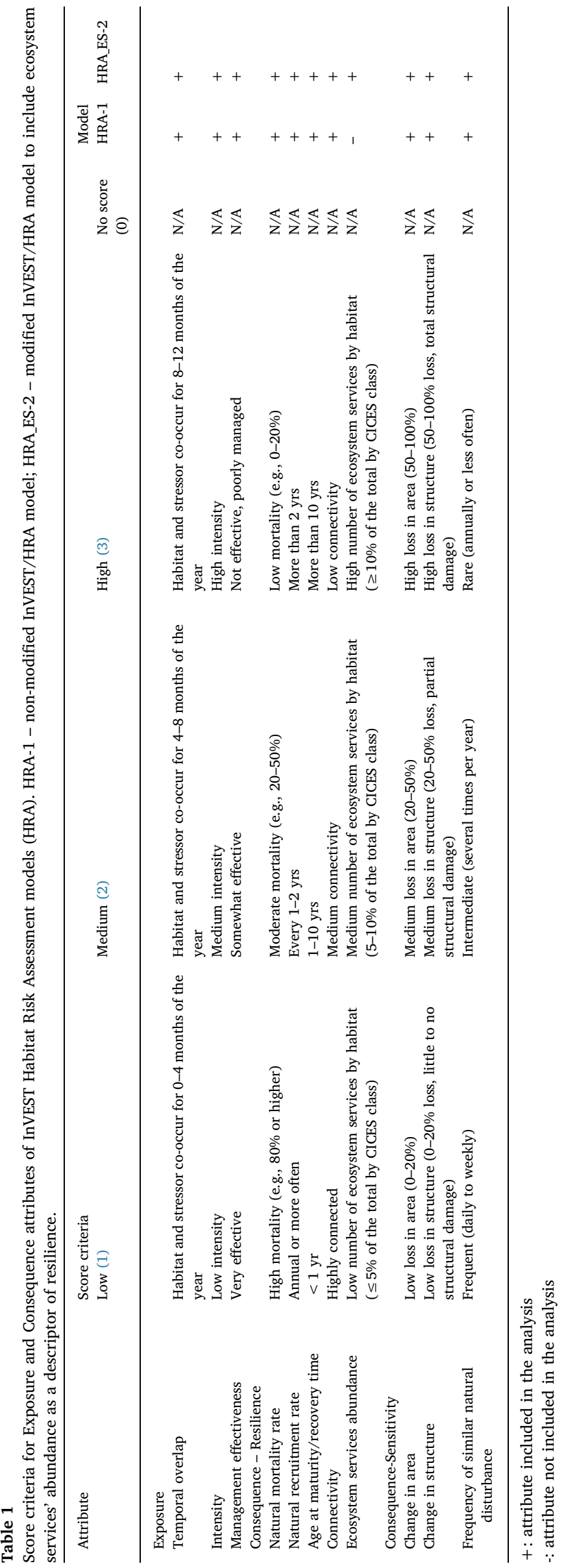



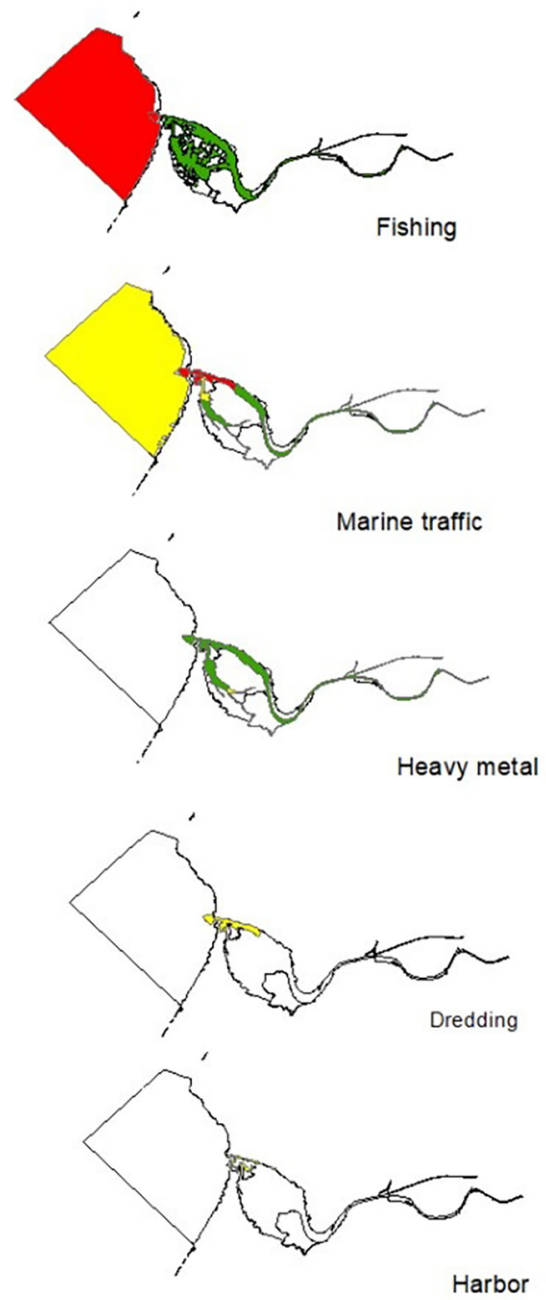
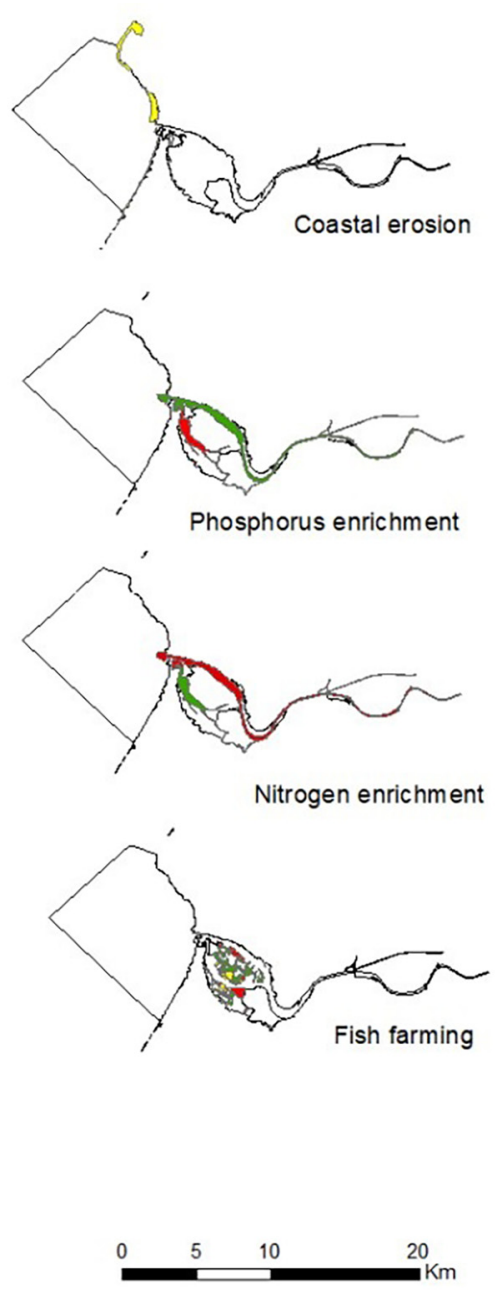
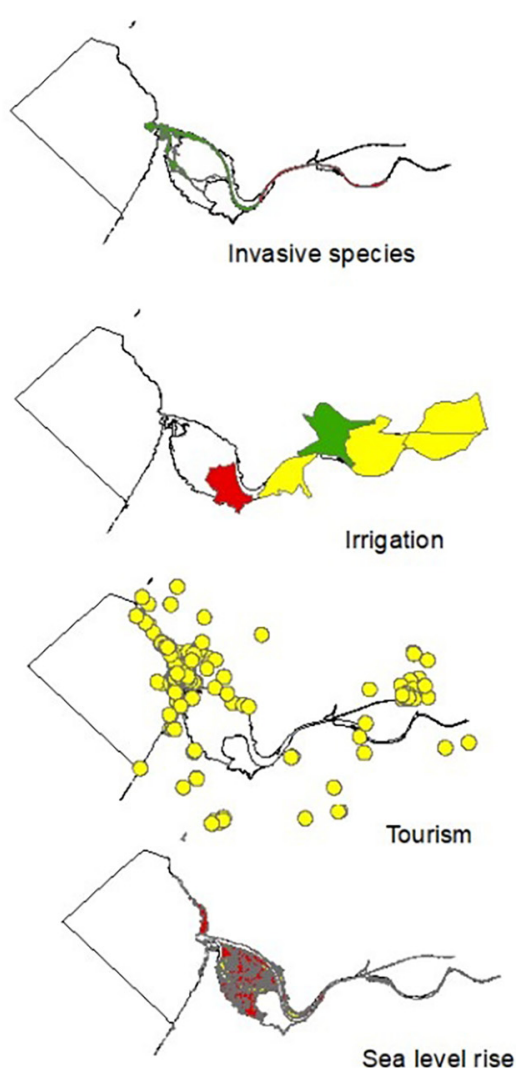

古

$1 \mathrm{~cm}=3,5 \mathrm{Km}$
Sea level rise

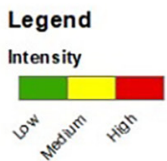

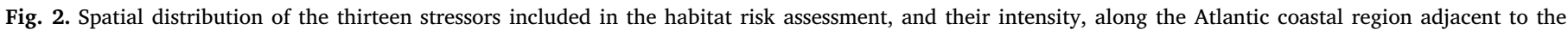
Mondego River (see Appendix A - Supplementary data for further details).

\subsubsection{The modified InVEST habitat risk assessment model (HRA_ES-2)}

The Habitat risk assessment (HRA) model, as described in the previous section, was modified to add the ecosystem services' abundance as a resilience attribute to describe the consequences of habitat exposure to a set of stressors (Table 1). As each ecosystem services' category, i.e., provisioning, regulation and cultural, contributes in a different manner to the resilience of ecosystems (Culhane et al., 2019; Liu et al. 2019), different weights have been assigned to each category: provisioning services pose the highest risk as they imply more human activities to get them (weight $=1$ ); regulation services pose the lowest risk as they do not imply invasive activities to be obtained (weight $=3$ ); cultural services pose a medium risk, considering that they represent an intermediate human impact (weight $=2$ ). As ecosystem services abundance was defined based on a high diversity of literature references - from scientific papers, to grey literature and social media (Caro et al., 2020) - a score of 2 was assigned to the data quality component (Table 2).

\subsubsection{Comparison between HRA-1 and HRA_ES-2 models}

To capture the main differences between the non-modified habitat risk assessment model (HRA-1) and the modified habitat risk assessment model that includes ecosystem services' abundance as a resilience descriptor (HRA_ES-2), it was applied the formula HRA_ES-2 - HRA-1 using the raster calculator tool from ArcGis 10.6.1. A histogram was produced to compare the mean risk values by habitat between the two models and a paired sample $t$-test between the mean risk scores of both models was performed to determine whether their mean difference is zero, assuming that data comes from related observations. A two-tailed hypothesis and a significance p-value of 0.05 was used. The $t$-test was selected because, according to a Shapiro-Wilk test, the distribution of the means followed a normal distribution.

In addition, a Principal Component Analysis (PCA) was performed to verify how much variance the two HRA models are able to explain and to understand if the correlation structure in the data was different among the two models. All (mean, max. and min.) exposure,

Table 2

Data quality and criteria weights scores.

\begin{tabular}{|c|c|c|c|}
\hline Data quality & $\begin{array}{l}\text { Best data (1) Supported by scientific } \\
\text { published papers that characterize the } \\
\text { study area }\end{array}$ & $\begin{array}{l}\text { Adequate data (2) Information based on data collected outside of the study } \\
\text { area, with similar characteristics and published. Data sources published in } \\
\text { European Union pages or inferred from studies whose objectives are not } \\
\text { specific to measure the variables of the model }\end{array}$ & $\begin{array}{l}\text { Limited data ( } 3 \text { ) Reasonable } \\
\text { inferences made by the user in the } \\
\text { study area }\end{array}$ \\
\hline Weight of criteria & Most important (1) & Moderately important (2) & Less important (3) \\
\hline
\end{tabular}


Table 3

Management scenarios built to assess the effect on seagrasses and saltmarshes habitats' risk.

\begin{tabular}{|c|c|c|c|}
\hline Scenario & & Goal & Description \\
\hline Scenario 1 & $\begin{array}{l}\text { One stressor management } \\
\text { scenario }\end{array}$ & $\begin{array}{l}\text { To assess how a small intensity management change in } \\
\text { the most impacting stressor could alter the habitats' } \\
\text { risk. }\end{array}$ & $\begin{array}{l}\text { Management effectiveness attribute (Exposure) of the most important } \\
\text { stressor was increased by one value. The stressor with the largest area } \\
\text { percentage under high risk was selected. }\end{array}$ \\
\hline Scenario 2 & $\begin{array}{l}\text { Multiple stressor } \\
\text { management scenario }\end{array}$ & $\begin{array}{l}\text { To assess how a large reduction in human pressures' } \\
\text { intensity in the most impacting stressors could alter the } \\
\text { habitats' risk. }\end{array}$ & $\begin{array}{l}\text { Management effectiveness attribute (Exposure) of all significant stressors } \\
\text { was increased to the maximum effectiveness in order to simulate a reduction } \\
\text { of human pressures' intensity to the minimum. All stressors for which more } \\
\text { than } 10 \% \text { of the habitat area is under high risk and/or more than } 50 \% \text { is } \\
\text { under medium risk, were selected. }\end{array}$ \\
\hline
\end{tabular}

consequence and risk score attributes were included in the analysis. All statistic data was calculated using Past 4.0, a free statistical software developed by a team from the University of Oslo (Hammer et al., 2001).

\subsection{Testing hypothesis 2}

To test whether a HRA model that accounts for ES abundance as an expression of environmental resilience and, at the same time, as a source of environmental stress due to demand, originates habitat risk values significantly different from other approaches that only take one of the assumptions into consideration (Hypothesis 2), the HRA_ES-2 model was compared to other approaches available in literature which also establish a relationship between habitat risk and ecosystem services. The modified HRA_ES-2 model was compared to the indices proposed by Cabral et al. (2015), Willaert et al. (2019) and Culhane et al. (2019).

To compare the results of the four approaches, first was calculated the influence of ES abundance on habitat risk scores based on the indices described by Cabral et al. (2015), Willaert et al. (2019) and Culhane et al. (2019). As such, the vulnerability index ( $\left.V i_{C}\right)$ of Cabral et al. (2015) was calculated based on Eq. (6), the vulnerability index $\left(V i_{W}\right)$ of Willaert et al. (2019) was calculated based on Eq. (7), and the ecosystem service supply (RESS) of Culhane et al. (2019) was calculated based on (Eq. (8))

$V i_{C}=\frac{R i}{A}$

$V i_{W}=R i \times A$

$R E S S=\frac{1}{\sqrt{(R i-1)^{2}+(A-1)^{2}}}$

where $R i$ is the cumulative mean risk by habitat obtained from the HRA- 1 model and $A$ is the total abundance of ecosystem services scores (Caro et al., 2020), normalized to $0-1$ by taking the maximum risk score as being equal to one, and the minimum risk score as being equal to 0 .

Then, a Friedman test (Pereira et al., 2015) followed by a Wilcoxon Pairwise test (Zimmerman and Zumbo, 1993) with Bonferroni correct p-values (Armstrong, 2014), suitable to compare the medians of more than two non-normal paired samples, was applied to determine whether there were any statistically significant differences between the risk scores of all four approaches. A significance p-value of 0.05 was used. The Friedman-test was selected because, according to a Shapiro-Wilk test, the distribution of the metrics did not follow a normal distribution.

Finally, a Principal Component Analysis (PCA) (Mishra et al., 2017) was applied to enable a different perspective and improve knowledge about the data structure. PCA is more commonly used as a method for feature extraction and dimensionality reduction, i.e., to create 'new' independent variables based on a combination of 'old' independent variables. In this process, researchers get to understand which 'new' variables predict better the dependent variable. This study is assuming that the cumulative mean risk score is the dependent variable, and that the four approaches (HRA_ES-2, $V i_{C}, V i_{W}$ and RESS) are the independent variables. Performing a PCA will allow understanding whether there is a relationship among the approaches (in the form of 'new' independent variables), what kind of relationship exists, what might distinguish the approaches among themselves and which are more important in predicting the cumulative risk score. To enable the comparison, the results of all four approaches were scaled to $0-1$, by subtracting the minimum value and dividing by the difference between the maximum and minimum value (Parravicini et al., 2012). All statistic data was calculated using Past 4.0 (Hammer et al., 2001).

\subsection{Testing hypothesis 3}

To test whether improving the management effectiveness score of the stressors that most contribute for habitats' risk, will decrease the HRA risk score (Hypothesis 3), management scenarios were tested for seagrass and saltmarsh habitats based on the modified HRA_ES-2 model. To do that, the first step was to describe the influence of stressors on seagrass and saltmarsh habitats' risk based on the area affected by each stressor. This information allowed us to identify the most impacting stressors, which, for the purpose of this study, correspond to those for which more than $10 \%$ of the habitat area is under high risk and/or more than $50 \%$ is under medium risk (see section 2.2.1 for further details on the definition of high and medium risk). Stressors were selected based on the HRA_ES-2 model results.

Then management scenarios were tested changing the management effectiveness attribute (Exposure) (Table 1), in the HRA_ES-2 model, of the stressors that most contribute for seagrass and saltmarsh habitats' risk. Two scenarios - the "one stressor management scenario" and the "multiple stressor management scenario" - were tested for each habitat (Table 3).

\section{Results}

\subsection{Are there differences among the modified and the non-modified InVEST/HRA models?}

The $t$-test, suitable for paired samples and normal distributions, confirms, with 95\% confidence, that there are significant statistical differences ( $\mathrm{p}<0.05$ ) between the non-modified HRA-1 model and the modified HRA_ES-2 model (including ecosystem services' abundance as a resilience attribute) (Table 4), meaning that the results cannot be explained by random variation only.

The Principal Component Analysis (Fig. 3) shows that the correlation structure in the data differs among the two models, confirming that including the abundance of ecosystem services as a descriptor of resilience influences the results. For both models, the mean exposure (E_MEAN) is the variable that most contributes to PC1 (loading score of 0.53 in HRA-1; loading score of 0.55 in HRA_ES-2), whereas the maximum exposure (E_MAX) is the variable that most contributes to PC2 (loading score of -0.66 in HRA-1; loading score of -0.69 in HRA_ES2) (Appendix A - Supplementary data). As a result, the right and upperside aggregates habitats with high mean exposure scores and low maximum exposure scores, whereas the left and lower-side aggregates habitats with low mean exposure scores and high maximum exposure scores. Despite the similarities among models, in the HRA-1 model, 
Table 4

Statistical results for hypothesis 1 . Shapiro-Wilk to evaluate whether the populations are drawn from normal distributions. Paired $t$-test to evaluate differences between two groups (Null hypothesis $\left(\mathrm{H}_{0}\right)$ : means of the two HRA models are equal).

\begin{tabular}{lllll}
\hline \multicolumn{2}{c}{ Shapiro-Wilk normality test } & & & \\
& Mean & Stand. Dev. & Shapiro-Wilk & p-value \\
\hline HRA-1 & 0.6924 & 0.1981 & 0.9723 & 0.7842 \\
HRA_ES-2 & 0.7781 & 0.2229 & 0.9526 & 0.3817 \\
paired $t$-test & & & & \\
& Mean difference & $95 \%$ conf. & t-value & p-value \\
& 0.0875 & $0.058267-0.11316$ & -6.5143 & $2.38 \mathrm{E}-06^{*}$ \\
\end{tabular}

* p-value $<0.05$

Note: The normality test shows that both the HRA-1 and the HRA_ES-2 populations do not deviate from nomality (p greater than 0.05 ), justifying the use of a parametric test ( $t$-test).

HRA-1 - non-modified InVEST/HRA model; HRA_ES-2 - modified InVEST/HRA model to include ecosystem services' abundance as a descriptor of resilience.

seagrass habitats (A2.6) are clearly separated from the remaining habitats as a result of a much higher mean exposure, whereas in the HRA_ES-2 model, the number of habitats with similar high mean exposure increases. As the results also show that the mean exposure is highly positively correlated with the mean risk $(\mathrm{R}=0.95$, $\mathrm{p}$ value $\left.=1.08 \mathrm{E}^{-11}\right)$ (Appendix A - Supplementary data), it is to expect a higher number of habitats with high mean risk with the HRA_ES-2 model than with the HRA-1 model.

Analyzing the results in more detail, the cumulative risk score shows that the highest score (Rmax) does not exceed the upper medium score limit, i.e. 1.86 for all habitat-stressor combinations (Appendix A Supplementary data), for both models, considering stressors altogether, which means that the Atlantic coastal region adjacent to the Mondego River does not show areas under high risk. The habitats with the largest area under medium risk differ between models and are located in transitional waters. For the HRA-1 model, two habitats - Estuarine littoral granule, very coarse to coarse sands (A2.1) and Estuarine seagrass bed (A2.6) show more than $40 \%$ of their area under medium risk, and thus are the habitats with higher risk. For the HRA_ES-2 model, six habitats are in the same conditions - Estuarine littoral granule, very coarse to coarse sands (A2.1), Estuarine littoral sandy mud and very fine to medium sands (A2.2), Estuarine littoral mud (A2.3), Estuarine seagrass bed (A2.6), Estuarine sublittoral granule and very coarse to coarse sands (A5.1), and Estuarine sublittoral sandy mud and very fine to medium sands (A5.2) (Table 5 and Fig. 4). For all the remaining

HRA-1 model
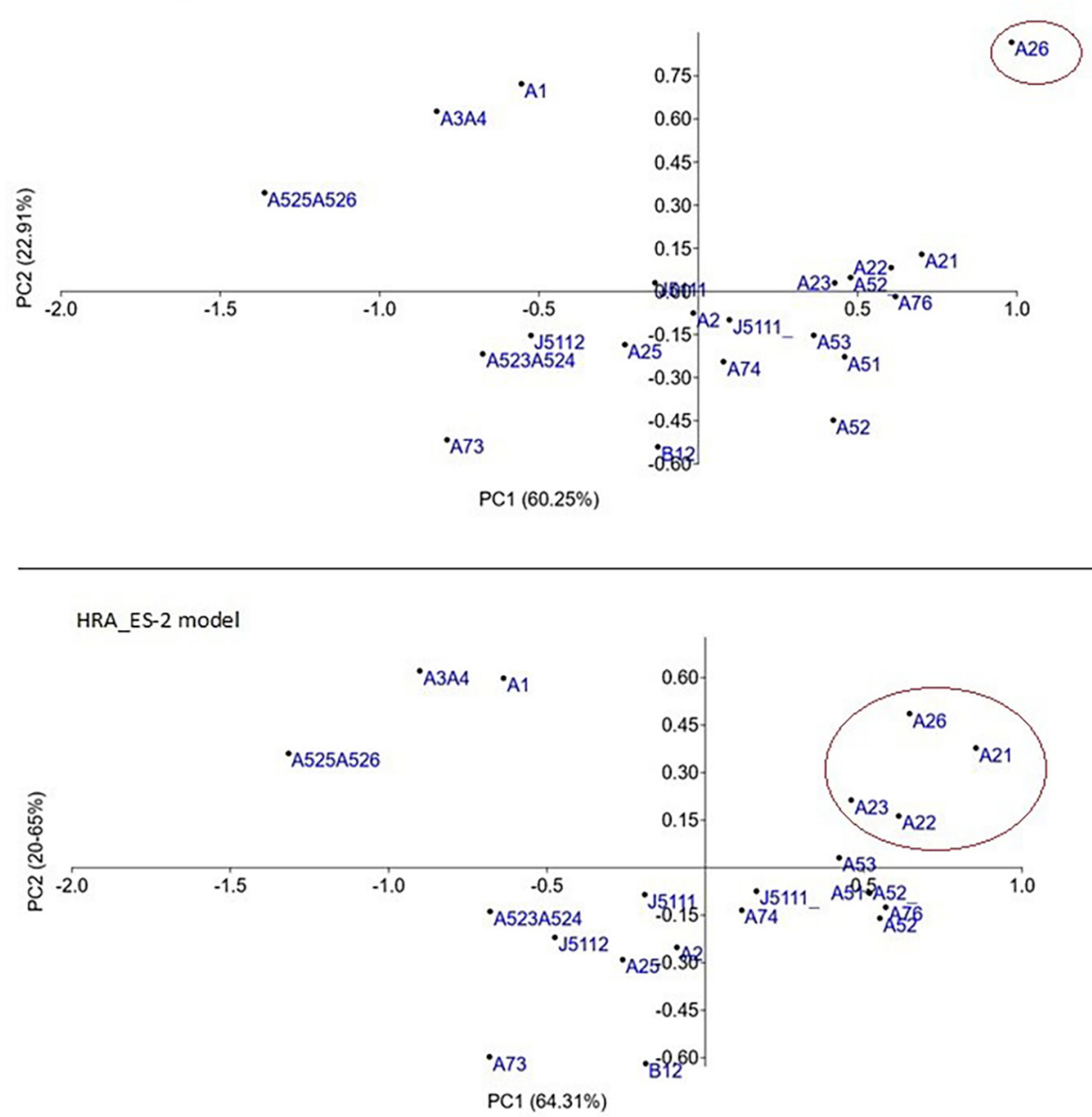

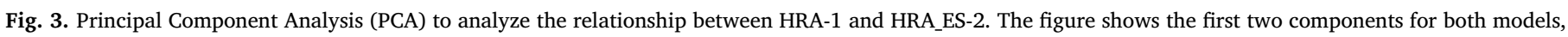

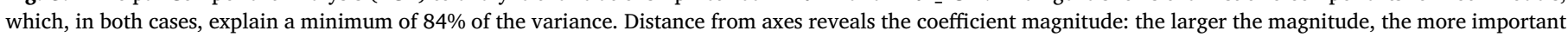

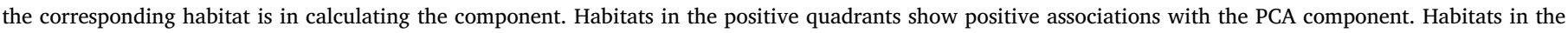

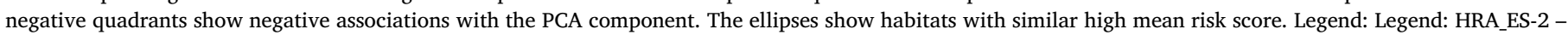

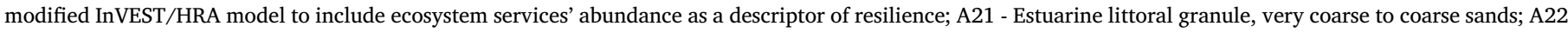
- Estuarine littoral sandy mud and very fine to medium sands; A23 - Estuarine littoral mud; A26 - Estuarine seagrass beds. 
Table 5

Cumulative risk scores for all stressors by habitat for medium risk habitats for the non-modified HRA-1 model and the modified HRA_ES-2 model.

\begin{tabular}{|c|c|c|c|c|c|c|}
\hline Habitat & R_MEAN & R_MIN & R_MAX & R_\%HIGH & R_\%MEDIUM & R_\%LOW \\
\hline \multicolumn{7}{|c|}{ HRA-1 model } \\
\hline $\mathrm{A} 21$ & 0.943974 & 0.483739 & 1.152391 & 0 & 40.22989 & 59.77011 \\
\hline A26 & 1.061587 & 0.931535 & 1.188512 & 0 & 86.04651 & 13.95349 \\
\hline \multicolumn{7}{|c|}{ HRA-_ES-2 model } \\
\hline A21 & 1.109863 & 0.714008 & 1.341436 & 0 & 80.23256 & 19.76744 \\
\hline A22 & 1.023484 & 0.317507 & 1.306909 & 0 & 66.80498 & 33.19502 \\
\hline $\mathrm{A} 23$ & 0.981223 & 0.464899 & 1.310804 & 0 & 58.59375 & 41.40625 \\
\hline A26 & 1.168636 & 0.601396 & 1.285765 & 0 & 95.83333 & 4.166667 \\
\hline A51 & 1.035931 & 0.293235 & 1.395215 & 0 & 65.66524 & 34.33476 \\
\hline A52 & 1.042899 & 0.293235 & 1.440711 & 0 & 64.83516 & 35.16484 \\
\hline
\end{tabular}

$\mathrm{R}$ - Cumulative risk score; MIN - minimum; MAX - maximum

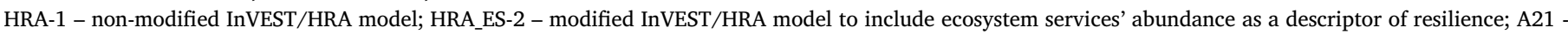

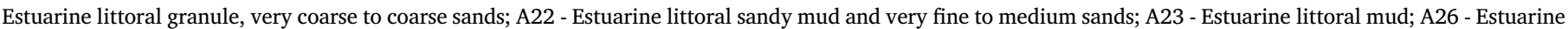
seagrass beds; A51 - Estuarine sublittoral granule and very coarse to coarse sands; A52 - Estuarine sublittoral sandy mud and very fine to medium sands

habitats, their area is classified as low risk (Fig. 4). Notice that, with exception for habitats A5.1 and A5.2 in the HRA_ES-2 model, the habitats with higher risk are all intertidal habitats (Fig. 4 and Appendix A - Supplementary data).

The results show that the medium risk areas are mainly located in the Mondego subsystem of the estuary (North branch), when running the HRA-1 model, but spread, after running the HRA_ES-2 model, to the Pranto subsystem of the estuary (South branch), as shown by the spatial distribution of the ecosystem risk, i.e., the sum of risk of all habitats in a grid cell, rather than a single habitat (Fig. 4).

The spatial differences among the results from the two models are highlighted in Fig. 5. Positive values, which occupy most of the study area, show areas where the risk has increased from the HRA-1 model to the HRA_ES-2 model. Negative values show the opposite trend. The largest positive differences are seen in the downstream area of the estuary and in the coastal area around the estuarine mouth. Negative differences, indicating a decrease in the cumulative risk score from one model to the other, are more intense in the upstream area of the estuary. Analyzing the cumulative risk scores by habitat (histogram in Fig. 5), than rather by grid cell, the cumulative risk scores only decrease for two low risk habitats: the Estuarine saltmarshes (A2.5), from transitional waters; and the Sandy beaches (B1.2) habitats, from coastal

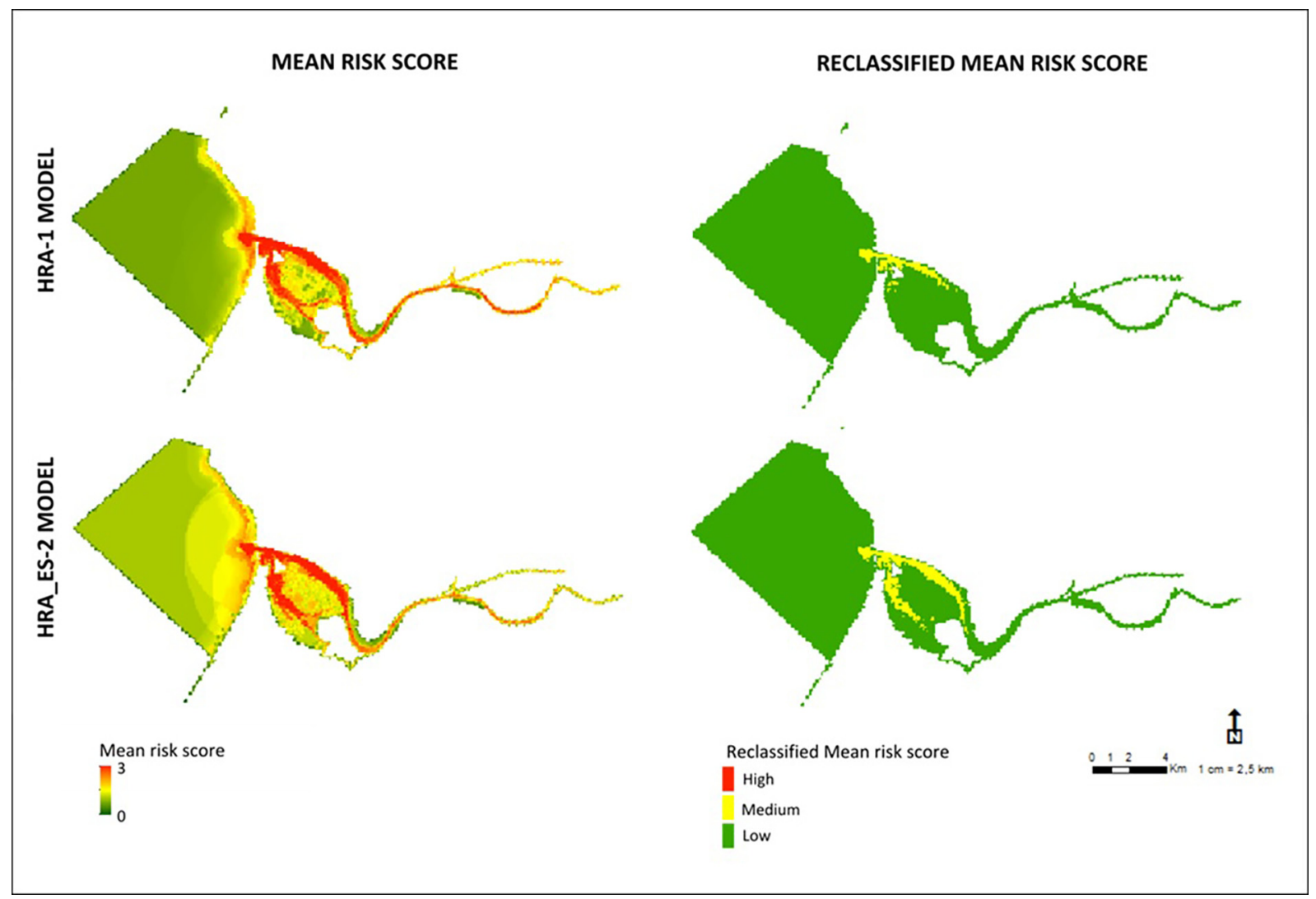

Fig. 4. Ecosystem risk map of the study area. The upper left image shows the average cumulative risk scores across all habitats from the HRA-1 model (non-modified InVEST/HRA model). The upper right image shows the reclassified average cumulative risk scores by categories for the HRA-1 model. The lower left image shows the average cumulative risk scores across all habitats from the HRA_ES-2 model (modified InVEST/HRA model to include ecosystem services' abundance as a descriptor of resilience). The lower right image shows the reclassified average cumulative risk scores by categories for the HRA_ES-2 model. Reclassification categories: High risk (red), medium risk, (yellow) and low risk (green). 


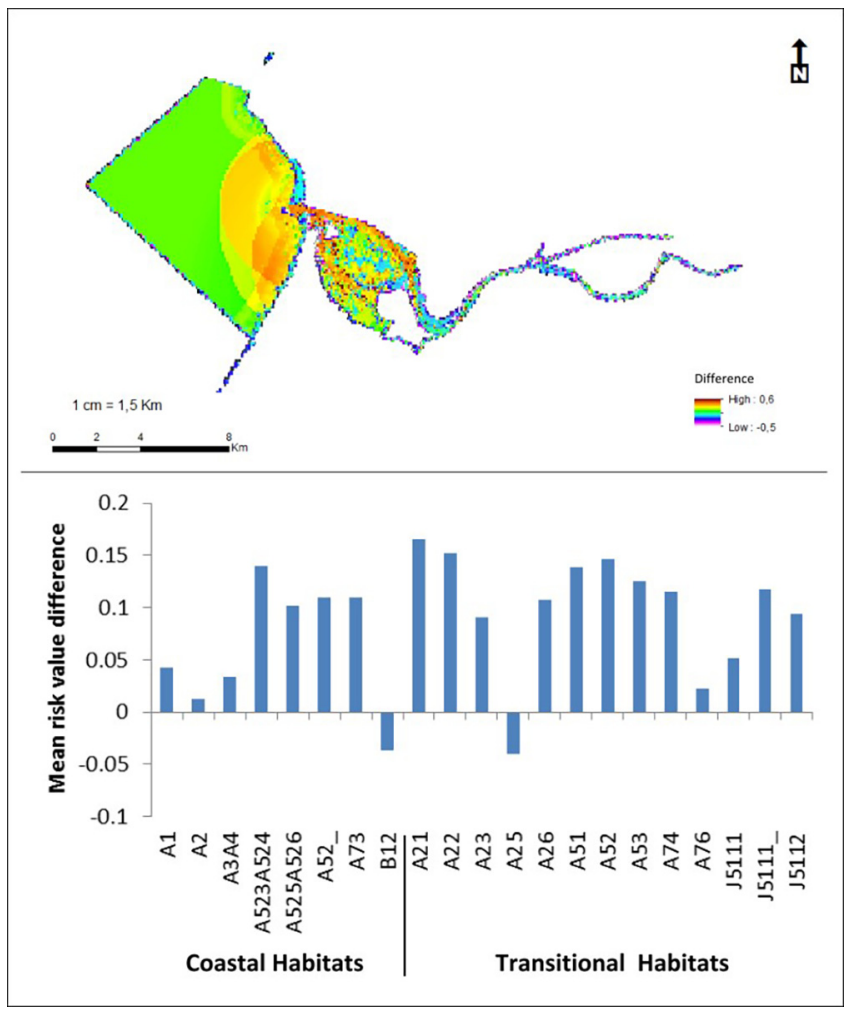

Fig. 5. Differences between the cumulative mean risk scores from HRA-1 model (non-modified InVEST/HRA model) and the HRA_ES-2 model (modified InVEST/HRA model to include ecosystem services' abundance as a descriptor of resilience). The upper map shows the spatial distribution of the differences by grid cell. The histogram shows the differences by habitat. A1 - Coastal rocky middle and supralittoral areas; A2 - Coastal supralittoral sedimentary areas; A21 - Estuarine littoral granule, very coarse to coarse sands; A22 - Estuarine littoral sandy mud and very fine to medium sands; A23 - Estuarine littoral mud; A25 - Estuarine saltmarshes; A26 - Estuarine seagrass bed; A3A4 - Infra and circalittoral rocky areas; A51 - Estuarine sublittoral granule very coarse to coarse sands; A52 - Estuarine sublittoral sandy mud and very fine to medium sands; A52 - Infralittoral or circalittoral sedimentary areas; A523A524 Infralittoral fine sand or infralittoral muddy sand areas; A525A526 Circalittoral fine sand or muddy sand areas; A53 - Estuarine sublittoral mud; B12 - Sandy beaches; J51511 - Water ponds; J5111_ - Aquaculture tanks; J5112 - Saltworks; A73 - Marine pelagic (0-200) waters; A74 - Estuarine pelagic waters of the South Mondego branch and Pranto River; A76 - Estuarine pelagic waters of the North branch of the Mondego River and upstream system.

waters.

\subsection{Are there significant statistical differences between the modified HRA_ES-2 model and the approaches from other authors?}

The Friedman test, suitable for paired samples drawn from nonnormal distributions, confirms, with $95 \%$ confidence, that there is a significant difference $(\mathrm{p}<0.05$ ) between the means of the HRA_ES-2 model, the vulnerability index proposed by Cabral et al. (2015) $\left(\mathrm{Vi}_{\mathrm{C}}\right)$, the vulnerability index proposed by Willaert et al. (2019) $\left(\mathrm{Vi}_{\mathrm{w}}\right)$ and the ecosystem service supply (RESS) value proposed by Culhane et al. (2019) (Table 6) (see Appendix A - Supplementary data for the risk values of $\mathrm{Vi}_{\mathrm{C}}, \mathrm{Vi}_{\mathrm{W}}$ and RESS). These results are confirmed by the Wilcoxon pairwise, with Bonferroni corrected $\mathrm{p}$ values. In particular, the pairwise test shows that the HRA_ES-2 model is significantly different from $\mathrm{Vi}_{\mathrm{W}} \mathrm{RESS}$, but not from $\mathrm{Vi}_{\mathrm{C}}$ (although the p-value is very close to 0.05 , and thus it is not possible to be entirely sure that the significant difference does not exist) (Table 6).

The PCA results confirm the statistically significant differences found with the Friedman test, clarifying the relationship between the
Table 6

Statistical results for hypothesis 2. The Shapiro-Wilk results evaluate whether the populations are drawn from normal distributions. The Friedman nonparametric test evaluates differences between groups and the Wilcoxon is used for pairwise comparison (Null hypothesis $\left(\mathrm{H}_{0}\right)$ : medians of the four risk approaches are equal).

\begin{tabular}{|c|c|c|c|c|}
\hline Shapiro-Wi & $\begin{array}{l}\text { ormality test } \\
\text { Shapiro-Wilk } \\
\text { W }\end{array}$ & p-value & Mean & Stand. dev \\
\hline HRA_ES-2 & 0.9526 & 0.3817 & 0.7780952 & 0.2229489 \\
\hline $\mathrm{Vi}_{\mathrm{C}}$ & 0.8943 & $0.02713^{*}$ & 0.579296 & 0.5012828 \\
\hline $\mathrm{Vi}_{\mathrm{W}}$ & 0.9006 & $0.03601^{*}$ & 0.4595304 & 0.3421495 \\
\hline RESS & 0.6642 & $0.00001 *$ & 3.342591 & 3.681292 \\
\hline \multicolumn{5}{|c|}{ Friedman test for equal means } \\
\hline Chi2 & p-value & & & \\
\hline 44.814 & $1.18 \mathrm{E}-10 *$ & & & \\
\hline \multicolumn{5}{|c|}{$\begin{array}{l}\text { Wilcoxon pairwise (above the diagonal) and bonferroni corrected p-values (below the } \\
\text { diagonal) }\end{array}$} \\
\hline & HRA_ES-2 & $\mathrm{Vi}_{\mathrm{C}}$ & $\mathrm{Vi}_{\mathrm{W}}$ & RESS \\
\hline HRA_ES-2 & & 190 & 224 & 228 \\
\hline $\mathrm{Vi}_{\mathrm{C}}$ & 0.05768 & & 3 & 231 \\
\hline $\mathrm{Vi}_{\mathrm{W}}$ & $0.00098^{*}$ & 1 & & 231 \\
\hline RESS & $0.00055^{*}$ & $0.00036^{*}$ & $0.00036^{*}$ & \\
\hline
\end{tabular}

* p-value $<0.05$

HRA_ES-2 - modified InVEST/HRA model to include ecosystem services' abundance as a descriptor of resilience;

$\mathrm{Vi}_{\mathrm{C}}-$ vulnerability index proposed by Cabral et al. (2015); $\mathrm{Vi}_{\mathrm{W}}$ - vulnerability index proposed by Willaert et al. (2019); RESS - index proposed by Culhane et al. (2019).

Note: A non-parametric test has been chosen because the normality test shows that the HRA_ES-2 population deviates from nomality ( $p>0.05)$, and also because the four models show very different standard deviations.

HRA_ES-2 model and the approaches proposed by other authors (Fig. 6). On component 1, all four approaches have similar positive loadings, indicating that this component is measuring habitat's risk, but on component 2, HRA_ES-2 has a very large positive loading, contrary to the other approaches (Table 7) indicating that this component is capturing the differentiating feature of the HRA_ES-2 model. The first two principal components explain $85 \%$ of the variance (Fig. 6 and Appendix A - Supplementary data).

\subsection{Does the habitat risk score decrease with increasing management effectiveness?}

To analyze changes in the habitat risk score within different management scenarios, the management effectiveness score of the HRA_ES2 model was modified only for those stressors that most impacted saltmarsh and seagrass habitats (Table 8). The results show that Estuarine saltmarshes (A2.5) are majorly affected by sea level change, organic enrichment due to nitrogen increase, irrigation and fishing; and that Estuarine seagrass bed (A2.6) are affected by all stressors, except coastal erosion and tourism activities (Table 8). Because sea level change is the stressor that contributes to the largest area percentage under high risk, in both habitats, it was selected for management improvement in scenario 1 (see section 2.6). The remaining marked stressors were selected for scenario 2 (see section 2.6).

After modifying the management effectiveness score for the stressors selected, the results indicate that the current situation has the highest cumulative mean risk score, followed by the "one stressor management scenario" (scenario 1). The "multiple stressor management scenario" (scenario 2) shows the lowest cumulative mean risk score. These trends are similar for both habitats (Table 9).

In saltmarsh habitats the increase in management effectiveness induces the disappearance of areas under high risk due to sea level changes and irrigation, and noticeably changes the area under medium risk due to irrigation and fishing to low risk. The same trend is not observed in seagrasses, for which the most noticeable change is the 


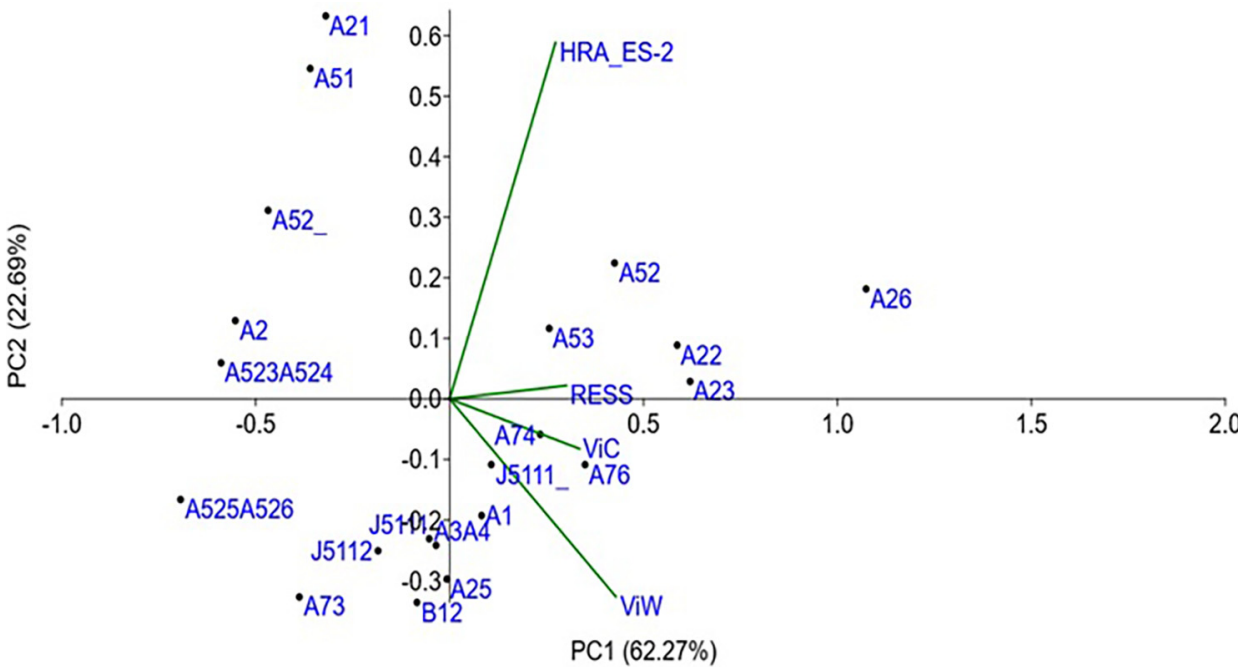

Fig. 6. Principal Component analysis (PCA) to analyze the relationship between the following risk assessment approaches: HRA_ES-2, ViC, ViW and RESS. The figure shows the first two components, which together explain $85 \%$ of the variance. Distance from axes reveals the coefficient magnitude: the larger the magnitude, the more important the corresponding approach is in calculating the component. Approaches in the positive quadrants show positive associations with the PCA component. Approaches in the negative quadrants show negative associations with the PCA component. Legend: HRA_ES-2 modified InVEST/HRA model to include ecosystem services' abundance as a descriptor of resilience; ViC - Vulnerability index proposed by Cabral et al. (2015); ViW - Vulnerability index proposed by Willaert et al. (2019); RESS index proposed by Culhane et al. (2019).
Table 7

Magnitude and direction of PCA coefficients for the following risk assessment approaches: HRA_ES-2, $V_{i C}, V i_{W}$ and RESS. The total variance explained by each component is between brackets. The values indicate the coefficient magnitude: the larger the magnitude, the more important the corresponding approach is in calculating the component. The positive and negative signs indicate the coefficient direction and whether there is a positive or negative association with the PCA component.

\begin{tabular}{lllll}
\hline \multicolumn{5}{c}{ PCA components } \\
& PC1 (62.2\%) & PC2 (22.8\%) & PC3 (12.5\%) & PC4 (2.4\%) \\
\hline HRA_ES-2 & 0.404435 & 0.867085 & -0.00077 & 0.290853 \\
$\mathrm{Vi}_{\mathrm{C}}$ & 0.492434 & -0.12164 & -0.7985 & -0.32421 \\
$\mathrm{Vi}_{\mathrm{W}}$ & 0.630359 & -0.48217 & 0.234199 & 0.561526 \\
$\mathrm{RESS}$ & 0.443383 & 0.029679 & 0.554572 & -0.70355 \\
\hline
\end{tabular}

HRA_ES-2 - modified InVEST/HRA model to include ecosystem services' abundance as a descriptor of resilience; $\mathrm{Vi}_{\mathrm{C}}$ - Vulnerability index proposed by Cabral et al. (2015); $\mathrm{Vi}_{\mathrm{W}}$ - Vulnerability index proposed by Willaert et al. (2019); RESS - index proposed by Culhane et al. (2019)
Table 9

Cumulative mean risk scores of saltmarsh and seagrass habitats in the current situation and for two management scenarios: the one stressor management scenario (scenario 1) and the multiple stressor management scenario (scenario 2). Results calculated using the HRA_ES-2 model.

\begin{tabular}{llll}
\hline Habitat & $\begin{array}{l}\text { Current situation } \\
\text { (HRA_ES-2) }\end{array}$ & $\begin{array}{l}\text { Scenario 1 } \\
\text { "one stressor" }\end{array}$ & $\begin{array}{l}\text { Scenario 2 } \\
\text { "multiple } \\
\text { stressor" }\end{array}$ \\
\hline Saltmarshes (A2.5) & 0.59 & 0.57 & 0.52 \\
Seagrasses (A2.6) & 1.17 & 1.15 & 1.03 \\
\hline
\end{tabular}

HRA ES-2 - modified InVEST/HRA model to include ecosystem services' abundance as a descriptor of resilience.

disappearance of areas under high risk due to sea level changes and a slight decrease of areas under medium risk due to fishing (Fig. 7).

\section{Discussion}

\subsection{Ecosystem services' abundance as a resilience descriptor}

The cumulative risk seems to be more in accordance with the socialenvironmental realm after adding ecosystem services' abundance as a resilience descriptor to the InVEST habitat risk assessment model. This is clear when comparing the risk score values of the Pranto subsystem

Table 8

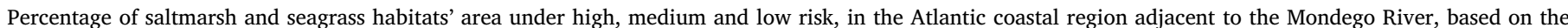
contribution of each stressor, for the HRA_ES-2 model.

\begin{tabular}{|c|c|c|c|c|c|c|}
\hline Stressor & $\begin{array}{l}\text { R_\%HIGH } \\
\text { Saltmarshes (A2.5) }\end{array}$ & R_\%MEDIUM & R_\%LOW & $\begin{array}{l}\mathrm{R}_{-} \% \mathrm{HIGH} \\
\text { Seagrasses (A2.6) }\end{array}$ & R_\%MEDIUM & R_\%LOW \\
\hline Fishing: recreative, commercial & 0.00 & $62.72^{* *}$ & 37.28 & 0.00 & $100 * *$ & 0.00 \\
\hline Coastal erosion & 0.00 & 0.00 & 100 & 0.00 & 0.00 & 100 \\
\hline Landfill/dredging/sand extraction & 0.00 & 0.00 & 100 & 0.00 & $58.33^{* *}$ & 41.67 \\
\hline Pollution by Fish farming & 1.72 & 12.93 & 85.34 & 0.00 & $93.75^{* *}$ & 6.25 \\
\hline Harbor activities & 0.00 & 4.96 & 95.04 & 0.00 & $100 * *$ & 0.00 \\
\hline Contamination by heavy metals & 0.00 & 21.12 & 78.88 & 0.00 & $97.92 * *$ & 2.08 \\
\hline Invasive species & 5.17 & 28.02 & 66.81 & 0.00 & $56.25^{* *}$ & 43.75 \\
\hline Irrigation (loss of freshwater discharge) & 5.6 & $81.90^{* *}$ & 12.5 & 0.00 & $95.83^{* *}$ & 4.17 \\
\hline Marine and estuary navigation traffic & 0.00 & 24.78 & 75.22 & 0.00 & $97.92^{* * *}$ & 2.08 \\
\hline Organic enrichment due to Nitrogen increase & $14.87^{*}$ & 20.47 & 64.66 & $25.00^{*}$ & $72.92^{* *}$ & 2.08 \\
\hline Organic enrichment due to Phosphorus increase & 0.00 & 33.62 & 66.38 & 0.00 & $97.92 * *$ & 2.08 \\
\hline Sea level changes & $27.37^{*}$ & $58.84^{* *}$ & 13.79 & $39.58^{*}$ & $60.42^{* *}$ & 0.00 \\
\hline Tourism activities & 0.00 & 5.17 & 94.83 & 0.00 & 0.00 & 100 \\
\hline
\end{tabular}

R - Cumulative risk score; HRA_ES-2 - modified InVEST/HRA model to include ecosystem services' abundance as a descriptor of resilience.

* more than $10 \%$ of the habitat area is under high risk

$* *$ more than $50 \%$ of the habitat area is under medium risk 


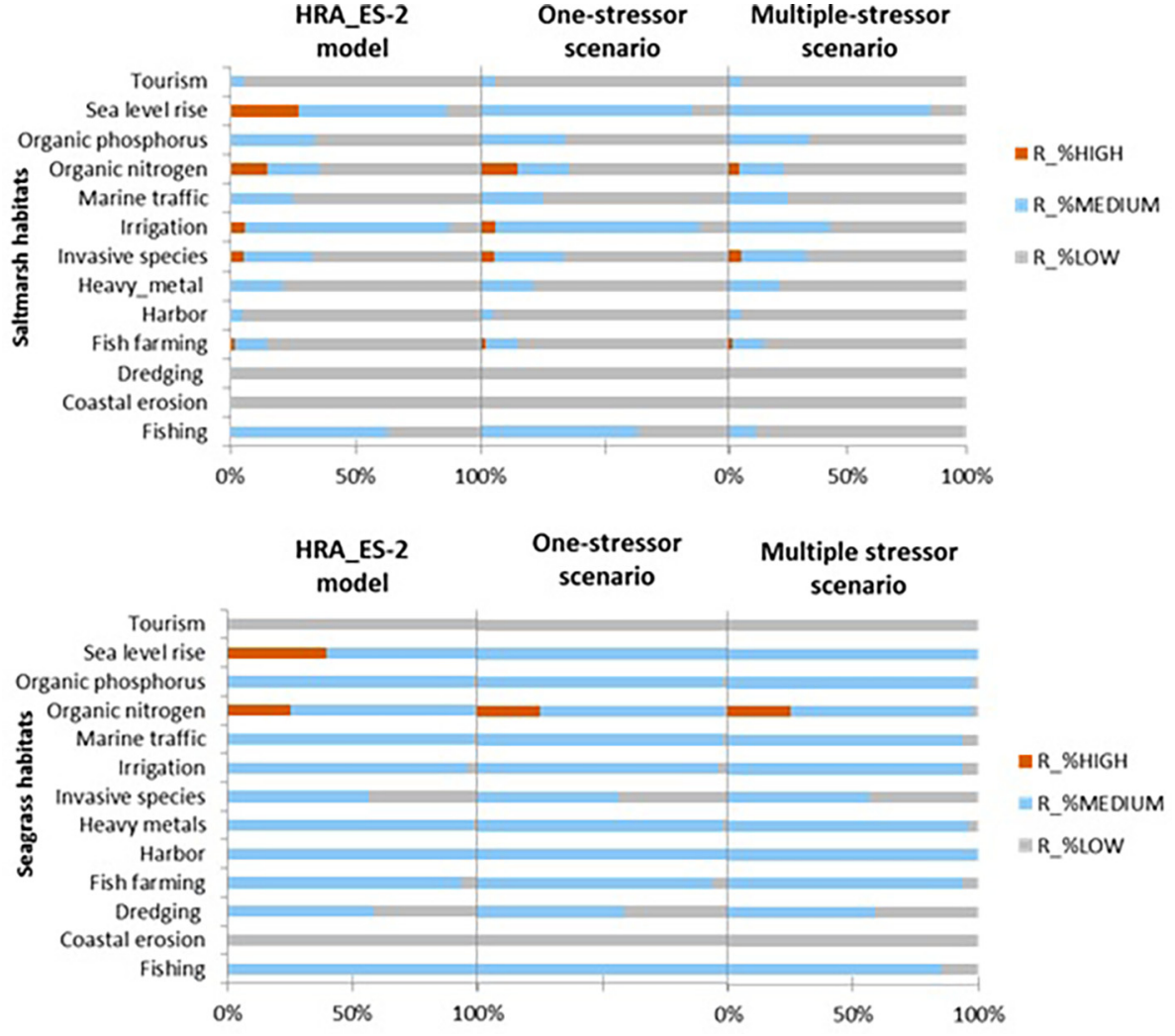

Fig. 7. Percentage of saltmarsh and seagrass habitats' area with high, medium and low risk under different stressors, for current situation (HRA_ES-2 model), one stressor management scenario (scenario 1) and multiple stressor management scenario (scenario 2). Legend: $\mathrm{R}$ - Cumulative risk score; HRA_ES-2 modified InVEST/HRA model to include ecosystem services' abundance as a descriptor of resilience.
(South branch) of the Mondego estuary from the two models tested: without (HRA-1 model) and with (HRA_ES-2 model) ecosystems services' abundance as a resilience descriptor. Pranto subsystem is one of the most vulnerable sectors of the case study area (e.g. Teixeira et al., 2008; Veríssimo et al., 2013a; Pinto et al., 2014), as it is highly sensitive to eutrophication (Flint et al., 1997, Dolbeth et al., 2007; Neto et al., 2008, 2010) due to its hydro-morphological characteristics (Duarte et al., 2001; Kenov et al., 2012; Veríssimo et al., 2013a). At the same time, the Pranto subsystem is highly important because it holds the largest and the more consistent patches of saltmarsh and seagrass habitats which provide a wide diversity and abundance of ecosystem services (Caro et al., 2020). Because model HRA-1 only accounts for the exposure-consequence combination without weighting the importance of the habitats for local development and environmental equilibria or, in other words, ecosystem services, it failed to detect the combined social and environmental vulnerability of the Pranto subsystem, i.e., the potential increase in vulnerability that comes from the impacts if ecosystem services are in demand, but also the decrease in vulnerability in habitats that provide higher abundances of ecosystem services. On the contrary, model HRA_ES-2, which took into account the ecosystem services' abundance, successfully detected it. A similar trend occurred for the coastline habitats and nearshore areas around the mouth of the Mondego estuary. These are low risk areas for which the cumulative risk score has increased after adding the ecosystems services' abundance as a resilience descriptor, indicating that in the presence of ecosystem services' demand, the vulnerability of coastline habitats may be higher than expected. This is in accordance with previous studies that show that stability is associated to species abundance rather than species richness (Pinto et al., 2013b), and that coastline and nearshore habitats are rich in species diversity, but low in species abundance (Teixeira et al., 2007).

The cumulative risk scores have, in fact, increased for almost all habitats when the ecosystem services abundance is included in the habitat risk assessment model. This is relevant from a precautionary principle (Kriebel et al., 2001), for four main reasons: 1) though an ecosystem might be capable of providing a service, it does not mean it is actually being used, but might be used in the future; 2) there can be a use of a service, even without an expression of demand, which frequently occurs with regulation services (Villamagna et al., 2013; Geijzendorffer and Roche, 2014); 3) the supply of ecosystem services may be associated to indirect pressures, for instance, road construction to increase value of previously inaccessible locations; and/or occasional low invasive pressures, such as ecosystem visitors for aesthetic/spiritual reasons; and 4) there can be a spatial mismatch between supply and demand (Syrbe and Grunewald, 2017). If, for these reasons, the stressors are overlooked, the exposure-consequence combination of the traditional habitat risk assessment model will not be able to reveal the full social and environmental vulnerability of the ecosystem.

The modified HRA_ES-2 model successfully establishes a relationship between impact risk and ecosystem service supply potential while accounting for two apparently conflicting assumptions: decrease in habitat vulnerability as a result of greater ecosystem adaptive capacity (measured by ecosystem service abundance) (Cabral et al., 2015) and increase in vulnerability as a result of exposure to ecosystem service demand (measured by the different weights assigned to the different categories of ES: provisioning, regulation and cultural) (Culhane et al., 2019). The model is in line with previous approaches (Cabral et al., 2015; Culhane et al., 2019; Willaert et al., 2019), but while these first perform a risk assessment and only then combine it with ecosystem services availability of habitats, the approach presented in this work integrates ecosystem services supply into the risk assessment model, introducing a spatial relationship between the pressures acting upon the system and the supply of ecosystem services, which provides a geographically more accurate risk assessment based on both impactful activities and ecosystem vulnerability.

\subsection{Counter-intuitive habitat risk results}

The Mondego subsystem of the estuary is dominated by medium risk areas, regardless of the model used. These results are counter-intuitive 
considering that this subsystem has low water residence time, which has a positive impact in eutrophication vulnerability (Duarte et al., 2001). However, they are consistent with the exposure to pressures such as: (a) the presence of the Figueira da Foz harbor, whose good operation depends on maintaining the navigation channel through dredging activities that cause instability of bottom habitats, leading to sediments re-suspension in the water column and turbidity (Ceia et al., 2013); (b) the proximity to the Figueira da Foz town, which contributes to water pollution (Pinto et al., 2013a; Teixeira et al., 2008); and (c) the embankement of the Mondego river channel which has triggered the replacement of natural habitats by artificial hard structures (e.g. harbor facilities, aquaculture farms, saltworks, artificial riverbanks), leading to ecosystem structure impoverishment (Marques et al., 1993; Cunha, 2002; Jørgensen et al., 2002; Ceia et al., 2011). In fact, previous studies have shown that the Mondego subsystem benthic communities are more disturbed than the Pranto subsystem communities (Marques et al., 1993; Van der Linden et al., 2016) - frequently dominated by opportunistic species, mainly bivalves, polychaetes, amphipods and oligochaetes (Chainho et al., 2006) -; and that there is an incapacity of intertidal areas to recover after big perturbations (Veríssimo et al., 2013a).

Results also indicate that risk mean score decreases for saltmarsh and sandy beaches habitats when adding ecosystem services abundance as a resilience descriptor (HRA_ES-2 model). As the exposure component has remained unchanged from one model (HRA-1) to another (HRA_ES-2), it would be expected a higher risk mean score just like for the remaining habitats, or, at least, the same risk mean score. However, a lower risk mean score is consistent with the type of ecosystem services supplied by these habitats (Caro et al., 2020). They both supply a wide diversity of regulation and cultural services, which indicate a high adaptive capacity to environmental change; and, at the same time, they show a very low number of provisioning services, and thus low human pressure to get them (Culhane et al., 2019), which is consistent with high resilience and low vulnerability.

\subsection{Stressors in the Atlantic coastal region adjacent to the Mondego River}

According to the model that include ecosystem services abundance in to habitat risk assessment, the stressors most contributing to habitat risk in the Atlantic coastal region adjacent to the Mondego River are the sea level change, organic enrichment due to nitrogen increase and, at a lesser extent, the presence of heavy metals. This agrees with previous research that shows that sea level rise is one of the most important threats to coastal environments (e.g. Teck et al., 2010; Almeida et al., 2016; Doubleday et al., 2017), affecting mainly estuaries (Boerema and Meire, 2017). Model-based projections advocate an increment of 0.26 to $0.77 \mathrm{~m}$ by 2100 for $1.5{ }^{\circ} \mathrm{C}$ of global warming (IPCC, Intergovernmental Panel on Climate Change, 2018), suggesting that areas with elevation lower or equal to $5 \mathrm{~m}$ above the sea level have the risk to disappear or to be naturally modified during the next centuries (e.g., Rova et al., 2018). In the Mondego estuary, studies have shown that a sea level rise of $0.50 \mathrm{~m}$ would induce a general increase in water depth in the lower areas of the estuary and large flooded areas (Ferreira et al., 2008; Santos et al., 2012). However, the margins of the estuary are already significantly occupied by urbanization and the inland displacement will not be possible. Sea level rise could change the hydrodynamics of coastal habitats, modifying the tidal pattern and inducing, in turn, changes in salinity, temperature, nutrients availability and oxygen demanding (MEA, Millennium Ecosystem Assessment, 2005). In the worst-case scenario the sea level changes could lead to the disappearance of entire habitats as saltmarshes and seagrasses (Couto et al., 2014).

Nitrogen enrichment as a stressor is confirmed by Marques et al. (2007) and Veríssimo et al. (2013a) which have revealed high nitrogen concentrations in the Mondego estuary, due mainly to agricultural areas located around the Mondego River. Nitrogen loading to aquatic ecosystems can lead to eutrophication, changing the ecosystem productivity, water clarity, and food web dynamics (Rhodes et al., 2017). In the Mondego estuary, high levels of eutrophication have been found in the Pranto subsystem favored by a low water residence time (Martins et al., 1997).

Finally, there is evidence of sediment contamination by heavy metals in the Mondego estuarine habitats (Vale et al., 2002), but concentrations are very low (Couto et al., 2013) - below the limits prescribed in the Guidance on the assessment and redevelopment of contaminated land (ICRLC, 1987) - and have a seasonal pattern, being higher in winter as a result of strong river discharges (Pereira et al., 2007). Despite the low concentrations found, heavy metals tend to be accumulated in the above- and belowground tissues of saltmarsh and seagrass plants and exported to the water column during plant release events, indicating that the plants of the ecosystem function not only as a sink for heavy metals, but also as a source of heavy metals to nearby systems, with implications on the ecosystem metal budget (Couto et al., 2013).

\subsection{Management of seagrass and saltmarsh habitats}

The results confirm the initial assumption that management measures to prevent the degradation of saltmarsh and seagrass habitats will be key to avoid the decrease of the environmental quality conditions of the study area and maintain the supply of socially and environmentally important ecosystem services. Since the end of the eighteenth century and until the end of the twentieth century, high-impact, land-based human activities (Doubleday et al., 2017) have caused the reduction of saltmarsh areas in about $20 \%$ of the original area (Castro and Freitas, 2011) and the significant reduction of seagrass habitats in the Pranto subsystem (South branch) (Neto et al., 2010). The results from the ES-2 model indicate that, currently, high risk areas in saltmarsh and seagrass habitats from the study area could be largely explained by the effect of sea level change and organic enrichment due to nitrogen increase, whereas medium risk areas can be explained by other stressors (irrigation, fishing, and sea level changes for saltmarshes; fishing, harbor activities, contamination by heavy metals, marine and estuary navigation traffic, organic enrichment due to phosphorus increase, irrigation, pollution by fish farming, organic enrichment due to nitrogen increase, sea level change, landfill/dredging/sand extraction and invasive species for seagrasses).

Scenario building simulating management improvements revealed that it is possible to change the condition of high-risk areas to medium risk and/or low risk sectors of saltmarsh and seagrass habitats exposed to stressors. With exception for the sector under high risk due to sea level changes, the change is more noticeable for saltmarshes than for seagrasses, whose large area under medium risk may hardly change its condition.

To prevent drowning of saltmarsh and seagrass due to sea level rise (Raposa et al., 2016; Sampath and Boski, 2016), adaptation measures should be applied (Leo et al., 2019). In the case study area, studies have shown that Scirpus maritimus, a species that accumulates large percentages of total carbon sequestered in the tissues, will disappear from the Mondego estuary if the sea level rise rates are confirmed (Couto et al., 2014). Measures to accommodate restoration and migration of these habitats include mechanisms of physical alteration of the environment; land acquisition and protection; and regulatory or policy interventions. In the case study, and based on its hydro-morphological characteristics and current land reclamation, the potential of the following adaptation measures should be analyzed: (a) hydraulic manipulation, which limits tidal flows, is usually used for agriculture, and could also be useful to promote wetlands restoration (Sandi et al., 2018); (b) stimulation of vertical sediment accretion, through the use of green infra structures or plant transplantation (Waycott et al., 2009); (c) promotion of land covenants, whereby a land owner restricts the use of their own property to protect natural resources; and d) land acquisition, in particular of 
abandoned private lands which may hold a strategic importance for the recovery of coastal processes.

To avoid the effects of nitrogen enrichment, especially in the Pranto subsystem, the water residence time must be maintained or increased (Lilleb $\varnothing$ et al., 2005), the nitrogen discharges should be avoided (Martins et al., 2001), the use of agricultural fertilizers controlled (Veríssimo et al., 2013b; Teixeira and Marques, 2016) and nitrogen inputs from fish farming activities reduced (Vasconcelos et al., 2007). These measures would prevent eutrophication events similar to those that occurred in the estuary throughout the period from 1986 to 1997 (Martins et al., 2001; Marques et al., 2007; Neto et al., 2010). Moreover, as scenarios analysis indicate that management measures will be insufficient to completely reduce high-risk areas related with this stressor, the better proposal could be coupling management actions focused on nitrogen enrichment with actions focused on enhancing ecosystem resilience, by managing stressors that diminish seagrass and saltmarsh biomass (Gladstone-Gallagher et al., 2018), like increased turbidity (Samper-Villarreal et al., 2016), fishing practices (Waycott et al., 2009), diseases (Hughes and Paramor, 2004) and storms (Cardoso et al., 2008).

Other management actions still need further research in order to analyze the actual effect on saltmarsh and seagrass habitats, such as the establishment of the maximum amount of water that could be extracted from rivers for irrigation before affecting the biotic communities (Pinto et al 2013a); and the control of invasive species, in particular Ruditapes philippinarum whose population dynamics, the factors controlling it (Dang, 2009) and the impacts in the Mondego estuary, are still poorly studied. In fact, estuaries are known for their resilience created by Environmental Homeostasis, i.e., their ability to withstand stress, both natural and anthropogenic, that comes from the ability to achieve a stable state by compensating for changes in the environment as a result of a homeostasis response that may operate at any level of biological organization, be it at the individual, population, community or ecosystem (Elliot and Quintino, 2007). This means that although seagrasses and saltmarshes seem to be sensitive to management effectiveness improvements, which is in accordance to historic management measures oriented to improve the habitat quality (Veríssimo et al., 2017), it is important to consider that ecosystems are context dependent and that within a background of high natural variability, it is more difficult to detect changes caused by anthropogenic stress (Veríssimo et al., 2013b). This difficulty is termed the Estuarine Quality Paradox (Elliot and Quintino, 2007). In addition, it is important to be aware that models can be improved in the presence of better data quality, ideally georeferenced (Caro et al., 2018), which might be achieved by strengthening monitoring programs (Singh et al., 2017; Sousa et al., 2017), which, in turn, should be considered as the first management action to conserve habitats, as well as the ecosystem services they deliver.

\section{Conclusions}

This study introduces a modified InVEST/HRA model that adds ecosystem services (ES) abundance as a resilience descriptor, assigning different weights to provisioning, regulation and cultural ecosystem services, based on whether there is a need for active exploitation. With this approach, the user is able to account not only for the resilience of ecosystems that arises from the presence of ecosystem services, but also for the sensitivity associated to the potential impacts if ecosystem services are in demand. As such, the methodology provides a risk assessment that takes into account not only the exposure-consequence component of risk, but also the importance of the habitats for local development and environmental equilibria.

Adding ES abundance as a resilience descriptor introduces significant and meaningful changes in the InVEST/HRA risk scores, compared to a model without resilience descriptors. This indicates that the resilience component from the InVEST/HRA model is flexible to accommodate other variables than those proposed by the developers, namely mortality rate, recruitment rate, age at maturity and connectivity. More specifically, the results indicate that the modified InVEST/HRA model is a novel approach to explore, in a spatial explicit manner, the influence of ecosystem services supply in habitats' risk, but also the effects of ecosystem state changes in the supply of ES.

A modified HRA model that accounts for ES abundance as an expression of environmental resilience and, at the same time, as a source of environmental stress due to demand, originates habitat risk values significantly different from those calculated applying the approaches suggested by Willaert et al. (2019) and Culhane et al. (2019), which only assume that ES are a source of environmental stress. At the same time, although not showing significant differences from the values calculated using the approach of Cabral et al. (2015), which only assumes ES as an expression of environmental resilience, the results are not strong enough to state a clear similarity between these two models. The results confirm that the modified InVEST/HRA is conceptually different from the approaches of other authors, which may become an advantage, especially if one is particularly interested in its spatial component, which is weak or absent in other approaches. The modified HRA has into consideration the spatial distribution of three important habitat risk components: habitats, exposure and ecosystem services provided by the habitats.

Changing the modified HRA_ES-2 model by increasing the management effectiveness score of the stressors that most contribute for risk of seagrass and saltmarsh habitats, decreases the risk score of these habitats. This is an indication that the approach is also suitable to evaluate management scenarios and the potential impacts on ecosystem services supply. With regard to the Atlantic coastal region adjacent to the Mondego River, the case study addressed in this research, the management scenarios applied, to ensure the sustainability of saltmarsh and seagrass habitats, show that there is still room for management improvement. This study is in line with others that show that tidal marshes and the ecosystem services they provide may be at risk from sea level changes. In the future, in detail studies could evaluate the feasibility of some of the adaptation measures proposed for this case study, either testing mechanisms on site; modeling the wetland habitat response to sea-level-rise or acting based on a precautionary principle implementing regulatory or policy interventions. The results are also in line with past studies in the estuary that show that nitrogen enrichment is one of the most concerning pressures, even though the actual effect of this pressure remains difficult to assess due to the natural variability of transitional systems, and there are no current signs of eutrophication impacts. This may be an indication that, currently, communities are capable to withstand, at some level, the current concentrations of nitrogen, possibly as a result of ecosystem homeostasis, but caution must be taken, as any ecosystem changes, such as those observed in the past, may rapidly cause a change in the Ecological Status of the system.

\section{Funding information}

This study was funded by PRONABEC through a PhD scholarship granted to Claudia Caro and supported by FCT (Portuguese National Board of Scientific Research) through the strategic project UID/MAR/ 04292/2020 granted to MARE (Marine and Environmental Sciences Centre), by the Regional Operational Programme CENTRO2020 within the scope of the project CENTRO-01-0145-FEDER-000006, by the National Operational Programme MAR2020 within the scope of the project ReSEt (MAR-01.04.02-FEAMP-0026), and by the LIFE Programme within the scope of the project LIFE ADAPTA BLUES Adaptation to Climate Change through management and restoration of European estuarine ecosystems (LIFE18 CCA/ES/001160). This work was also funded by FCT, through a Sabbatical grant (SFRH/BSAB/ 150395/2019) hold by Pedro P. Cunha (Programa Operacional Capital Humano). 


\section{CRediT authorship contribution statement}

Claudia Caro: Conceptualization, Methodology, Formal analysis, Investigation, Writing - original draft, Visualization, Funding acquisition. Joảo Carlos Marques: Validation, Writing - review \& editing, Project administration, Funding acquisition. Pedro P. Cunha: Investigation, Resources, Writing - review \& editing, Visualization. Zara Teixeira: Validation, Formal analysis, Investigation, Resources, Data curation, Writing - review \& editing, Visualization, Supervision, Funding acquisition.

\section{Declaration of Competing Interest}

The authors declare that they have no known competing financial interests or personal relationships that could have appeared to influence the work reported in this paper.

\section{Acknowledgments}

Authors would like to thank Dr. Vasco M. Mantas for his advice on some GIS tools and the anonymous reviewers for the constructive and valuable comments and suggestions to improve the manuscript.

\section{Appendix A. Supplementary data}

Supplementary data to this article can be found online at https:// doi.org/10.1016/j.ecolind.2020.106426.

\section{References}

Almeida, D., Rocha, J., Neto, C., Arsénio, P., 2016. Landscape metrics applied to formerly reclaimed saltmarshes: a tool to evaluate ecosystem services? Estuar. Coast. Shelf Sci. 181, 100-113. https://doi.org/10.1016/j.ecss.2016.08.020.

Arkema, K.K., Verutes, G., Bernhardt, J.R., Clarke, C., Rosado, S., Canto, M., Wood, S.A., Ruckelshaus, M., Rosenthal, A., McField, M., De Zegher, J., 2014. Assessing habitat risk from human activities to inform coastal and marine spatial planning: a demonstration in Belize. Environ. Res. Lett. 9, 114016. https://doi.org/10.1088/17489326/9/11/114016.

Arkema, K.K., Verutes, G.M., Wood, S.A., Clarke-Samuels, C., Rosado, S., Canto, M. Rosenthal, A., Ruckelshaus, M., Guannel, G., Toft, J., Faries, J., Silver, J.M., Griffin, R., Guerry, A.D., 2015. Embedding ecosystem services in coastal planning leads to better outcomes for people and nature. Proc. Natl. Acad. Sci. 112 (24), 7390-7395. https://doi.org/10.1073/pnas.1406483112.

Armstrong, R.A., 2014. When to use the Bonferroni correction. Ophthalmic Physiological Optics. 34 (5), 502-508.

Arnan, X., Molowny-Horas, R., Blüthgen, N., 2019. Food resource exploitation and functional resilience in ant communities found in common Mediterranean habitats. Sci. Total Environ. 684, 126-135. https://doi.org/10.1016/j.scitotenv.2019.05.260.

Baeta, A., Niquil, N., Marques, J.C., Patrício, J., 2011. Modelling the effects of eutrophication, mitigation measures and an extreme flood event on estuarine benthic food webs. Ecol. Model. 222 (6), 1209-1221. https://doi.org/10.1016/j.ecolmodel. 2010.12.010.

Ban, N.C., Alidina, H.M., Ardron, J.A., 2010. Cumulative impact mapping: advances, relevance and limitations to marine management and conservation, using Canada's Pacific waters as a case study. Mar. Policy 34, 876-886. https://doi.org/10.1016/j. marpol.2010.01.010.

Barbier, E.B., Hacker, S.D., Kennedy, C., Koch, E.M., Stier, A.C., Silliman, B.R., 2011. The value of estuarine and coastal ecosystem services. Ecol. Monogr. 81 (2), 169-183. https://doi.org/10.1890/10-1510.1.

Bessa, F., Barría, P., Neto, J.M., Frias, J.P.G.L., Otero, V., Sobral, P., Marques, J.C., 2018. Occurrence of microplastics in commercial fish from a natural estuarine environment. Mar. Pollut. Bull. 128, 575-584. https://doi.org/10.1016/j.marpolbul.2018.01.044.

Bettencourt, A., Bricker, S.B., Ferreira, J.G., Franco, A., Marques, J.C., Melo, J.J., Nobre, A., Ramos, L., Reis, C.S., Salas, F., Silva, M.C., Simas, T., Wolff, W., 2004. Typology and Reference Conditions for Portuguese Transitional and Coastal Waters. INAG, IMAR, pp. 99.

Biggs, R., Schlüter, M., Biggs, D., Bohensky, E.L., BurnSilver, S., Cundill, G., Dakos, V., Daw, T.M., Evans, L.S., Kotschy, K., Leitch, A.M., Meek, C., Quinlan, A., RaudseppHearne, C., Robards, M.D., Schoon, M.L., Schultz, L., West, P.C., 2012. Toward principles for enhancing the resilience of ecosystem services. Towards principles for enhancing the resilience of ecosystem services. Annu. Rev. Environ. Resour. 37 421-448. https://doi.org/10.1146/annurev-environ-051211-123836.

Boerema, A., Meire, P., 2017. Management for estuarine ecosystem services: A review. Ecol. Eng. 98, 172-182. https://doi.org/10.1016/j.ecoleng.2016.10.051.

Borja, A., Elliott, M., Andersen, J.H., Berg, T., Carstensen, J., Halpern, B.S., Heiskanen, A.S., Korpinen, S., Lowndes, J.S.S., Martin, G., Rodriguez-Ezpeleta, N., 2016. Overview of integrative assessment of marine systems: the ecosystem Approach in practice. Frontiers in Marine Sciences 3, 20. https://doi.org/10.3389/fmars.2016.00020.

Botelho, M.J., Vale, C., Ferreira, J.G., 2019. Seasonal and multi-annual trends of bivalve toxicity by PSTs in Portuguese marine waters. Sci. Total Environ. 664, 1095-1106. https://doi.org/10.1016/j.scitotenv.2019.01.314.

Brock, T., Bigler, F., Frampton, G., Hogstrand, C., Luttik, R., Martin-Laurent, F., Topping, C.J., van der Werf, W., Rortais, A., 2018. Ecological recovery and resilience in environmental risk assessments at the European Food Safety Authority. Integr. Environ. Assess. Manage. 14, 586-591. https://doi.org/10.1002/ieam.4079.

Cabral, P., Levrel, H., Schoenn, J., Thiébaut, E., Le Mao, P., Mongruel, R., Rollet, C., Dedieu, K., Carrier, S., Morisseau, F., Daures, F., 2015. Marine habitats ecosystem service potential: a vulnerability approach in the Normand-Breton (Saint Malo) Gulf, France. Ecosyst. Serv. 16, 306-318. https://doi.org/10.1016/j.ecoser.2014.09.007.

Cardoso, P.G., Pardal, M.A., Lillebø, A.I., Ferreira, S.M., Marques, J.C., Raffaelli, D., 2004. Dynamic changes of seagrass assemblages under eutrophication and implications for recovery. J. Exp. Mar. Biol. Ecol. 302, 233-248. https://doi.org/10.1016/j.jembe. 2003.10.014.

Cardoso, P.G., Raffaelli, D., Pardal, M.A., 2008. The impact of extreme weather events on the seagrass Zostera noltii and related Hydrobia ulvae population. Mar. Pollut. Bull. 56 (2008), 483-492. https://doi.org/10.1016/j.marpolbul.2007.11.006.

Caro, C., Pinto, R., Marques, J.C., 2018. Use and usefulness of open source spatial databases for the assessment and management of European coastal and marine ecosystem services. Ecol. Ind. 95, 41-52. https://doi.org/10.1016/j.ecolind.2018.06.070.

Caro, C., Cunha, P.P., Marques, J.C., Teixeira, Z., 2020. Identifying ecosystem services research hotspots to illustrate the importance of site-specific research: an Atlantic coastal region case study. Environmental and Sustainability Indicators 95 (1), 41-52. https://doi.org/10.1016/j.indic.2020.100031.

Carpenter, S., Walker, B., Anderies, J.M., Abel, N., 2001. From Metaphor to Measurement: Resilience of What to What? Ecosystems 4, 765-781. https://doi.org/10.1007/ s10021-001-0045-9.

Castro, P., Freitas, H., 2011. Spatial distribution of halophytes in the Mondego salt marsh and plant responses to environmental conditions. Ecological Questions 14 (2011), 17-18. https://doi.org/10.2478/v10090-011-0004-9.

Castro, N., Félix, P.M., Neto, J.M., Cabral, H., Marques, J.C., Costa, M.J., Costa, J.L., 2016. Fish communities' response to implementation of restoring measures in a highly artificialized estuary. Ecol. Ind. 67, 743-752. https://doi.org/10.1016/j. ecolind.2016.03.040.

Castro, N., Penedos, C., Félix, P., Chaino, P., Pereira, T., Costa, M.J., Almeida, A.J., Adão, H., Costa, J.L., 2019. Structural and functional composition of fish communities associated to Zostera noltii meadows as a response to natural habitat recovery. Ecol. Ind. 106, 105435. https://doi.org/10.1016/j.ecolind.2019.05.066.

Ceia, F.R., Patrício, J., Franco, J., Pinto, R., Fernández-Boo, S., Losi, V., Marques, J.C., Neto, J.M., 2011. Assessment of estuarine macrobenthic assemblages and ecological quality status at a dredging site in a southern Europe estuary. Ocean Coast. Manag. 72, 80-92. https://doi.org/10.1016/j.ocecoaman.2011.07.009.

Ceia, F.R., Patrício, J., Franco, J., Pinto, R., Fernández-Boo, S., Losi, V., Marques, J.C., Neto, J.M., 2013. Assessment of estuarine macrobenthic assemblages and ecological quality status at a dredging site in a southern Europe estuary. Ocean Coast. Manag. 72, 80-92. https://doi.org/10.1016/j.ocecoaman.2011.07.009.

Chainho, P., Costa, J.L., Chaves, M.L., Lane, M.F., Dauer, D.M., Costa, M.J., 2006 Seasonal and spatial patterns of distribution of subtidal benthic invertebrate communities in the Mondego River, Portugal - a poikilohaline estuary. Hydrobiologia 555, 59-74. https://doi.org/10.1007/s10750-005-1132-2.

Couto, T.C., Duarte, B., Caçador, I., Baeta, A., Marques, J.C., 2013. Salt marsh plants carbon storage in a temperate Atlantic estuary illustrated by a stable isotopic analysis-based approach. -. Ecol. Ind. 32, 305-311. https://doi.org/10.1016/j.ecolind. 2013.04.004.

Couto, T., Martins, I., Duarte, B., Cacador, I., Marques, J.C., 2014. Modelling the effects of global temperature increase on the growth of salt marsh plants. Appl. Ecol. Environ. Res. 12 (3), 753-764. https://doi.org/10.15666/aeer/1203_753764.

Culhane, F., Teixeira, H., Nogueira, A.J.A., Borgwardt, F.T., F., Lillebø, A., Piet, G., Kuemmerlen, M., McDonald, H., O'Higgins, T., Barbosa, A.L., van der Wal, J.T. Iglesias-Campos, A., Arevalo-Torres, J., Barbière, J., Robinson, L.A., 2019. Risk to the supply of ecosystem services across aquatic ecosystems. Science of The Total Environment 660, 611-621. https://doi.org/10.1016/j.scitotenv.2018.12.346.

Cullen-Unsworth, L.C., Nordlund, L.M., Paddock, J., Baker, S., McKenzie, L.J., Unsworth, R.K.F., 2014. Seagrass meadows globally as a coupled social-ecological system: implications for human wellbeing. Mar. Pollut. Bull. 83, 387-397. https://doi.org/10. 1016/j.marpolbul.2013.06.001.

Cunha, P.P., Pinto, J., Dinis, J.L., 1997. Evolução da fisiografia e ocupação antrópica na área estuarina do Rio Mondego e região envolvente (Portugal centro-oeste) desde 1947. Territorium 4, 99-124.

Cunha, P.P., Dinis, J.L., André, J.N., 1998. Interacção entre as operações de dragagem no Porto da Figueira da Foz e a dinâmica sedimentar no Estuário do Mondego e costa adjacente (Portugal central). ln Proceedings of the Seminário sobre Dragagens, dragados e ambientes costeiros. Edited by Associação Eurocoast-Portugal, Lisboa, pp. $27-45$

Cunha, P.P., Dinis, J. 2002. Sedimentary dynamics of the Mondego estuary. In M. A. Pardal, J. C. Marques \& M. A. S. Graça (editors), Aquatic ecology of the Mondego river basin. Global importance of local experience. Chapter 1.4, pp. 43-62, Imprensa da Universidade, Univ. Coimbra. https://digitalis.uc.pt/pt-pt/livro/aquatic_ecology_ mondego_river_basin_global_importance_local_experience.

Cunha, P.P., Campar, A., Ramos, A., Cunha, L., Dinis, J., 2006. Geomorphology and coastal dynamics of the Figueira da Foz region. Publicações da Associação Portuguesa de Geomorfólogos, Vol. IV, APGeom, Lisboa, 35 -46.

Dang, C., 2009. Dynamique des populations de palourdes japonaises 
(Ruditapesphilippinarum) dans le bassin d'Arcachon, conséquences sur la gestion des pop-ultions exploitées. Ph.D. Thesis. Université de Bordeaux.

Dinis, J.L., Cunha, P.P., 1998. Impactes antrópicos no sistema sedimentar do Estuário do Mondego. Sociedade e Território, Revista de estudos urbanos e regionais 27, 3-15.

Dolbeth, M., Cardoso, P.G., Ferreira, S.M., Verdelhos, T., Raffaelli, D., Pardal, M.A., 2007. Anthropogenic and natural disturbance effects on a microbenthic estuarine community over a 10-year period. Mar. Pollut. Bull. 54, 576-585. https://doi.org/10.1016/j. marpolbul.2006.12.005.

Doubleday, Z.A., Jones, A.R., Deveney, M.R., Ward, T.M., Gillanders, B.M., 2017. Eigh habitats, 38 threats and 55 experts: Assessing ecological risk in a multi-use marine region. PLoS ONE 12 (5), e0177393. https://doi.org/10.1371/journal.pone. 0177393.

Duarte, A.A.L.S., Pinho, J.L.S., Pardal, M.A., Neto, J.N., Vieira, J.P., Santos, F.S., 2001 Effect of residence times on River Mondego estuary eutrophication vulnerability. Water Science \& Technology, 44(2-3), 329:336. https://doi.org/10.2166/wst.2001. 0786.

Duggan, J.M., Eichelberger, B.A., Ma, S., Lawler, J.J., Ziv, G., 2015. Informing management of rare species with an approach combining scenario modeling and spatially explicit risk assessment. Ecosyst. Health Sustainability 1, 1-18. https://doi.org/10. 1890/EHS14-0009.1.

Elliot, M., Quintino, V., 2007. The Estuarine Quality Paradox, Environmental Homeostasis and the difficulty of detecting anthropogenic stress in naturally stressed areas. Mar. Pollut. Bull. 54 (6), 640-645. https://doi.org/10.1016/j.marpolbul.2007. 02.003.

Falcão, J., Marques, S.C., Pardal, M.A., Marques, J.C., Primo, A.L., Azeiteiro, U.M., 2012. Mesozooplankton structural responses in a shallow temperate estuary following restoration measures. Estuarine Coastal and Shelf. Science 112, 23e30. https://doi.org/ 10.1016/j.ecss.2011.06.007.

Ferreira, J.G., Nobre, A.M., Simas, T.C., Silva, M.C., Newton, A., Bricker, S.B., Wolff, W.J., Stacey, P.E., Sequeira, A., 2006. A methodology for defining homogeneous water bodies in estuaries e Application to the transitional systems of the EU Water Framework Directive. Estuar. Coast. Shelf Sci. 66, 468-482. https://doi.org/10. 1016/j.ecss.2005.09.016.

Ferreira, Ó., Dias, J.A., Taborda, R., 2008. Implications of Sea-Level Rise for Continental Portugal. Retrieved from www.jstor.org/stable/30137838.. J. Coastal Res. 24 (2), 317-324.

Flindt, M.R., Kamp-Nielsen, L., Marques, J.C., Pardal, M.A., Bocci, M., Bendoricchio, G., Salomonsen, J., Nielsen, S.N., Jørgensen, S.C., 1997. Description of the three shallow estuaries: Mondego River (Portugal), Roskilde Fjord (Denmark) and the Lagoon of Venice (Italy). Ecol. Model. 102, 17-31. https://doi.org/10.1016/S0304-3800(97) 00092-6.

Folke, C., 2006. Resilience: the emergence of a perspective for social-Ecological systems analyses. Global Environ. Change 16 (3), 253-267. https://doi.org/10.1016/j. gloenvcha.2006.04.002.

Franco, J.N., Ceia, F.R., Patricio, J., Modesto, V., Thompson, J., Marques, J.C., Neto, J.M., 2012. Population dynamics of Corbicula fluminea (Muller, 1774) in mesohaline and oligohaline habitats: invasion success in a Southern Europe estuary. Estuarine Coastal and Shelf Science. 112, 31-39. https://doi.org/10.1016/j.ecss.2011.07.014.

Gaspar, R., Marques, L., Pinto, R., Baeta, A., Pereira, L., Martins, I., Marques, J.C., Neto, J.M., 2017. Origin here, impact there-the need of integrated management for river basins and coastal areas. Ecol. Ind. 72, 794-802. https://doi.org/10.1016/j.ecolind. 2016.09.013.

Geijzendorffer, I.R., Roche, P.K., 2014. The relevant scales of ecosystem services demand. Ecosyst. Serv. 10, 49-51. https://doi.org/10.1016/j.ecoser.2014.09.002.

Gladstone-Gallagher, R.V., Hughes, R.W., Douglas, E.J., Pilditch, C.A., 2018. Biomassdependent seagrass resilience to sediment eutrophication. J. Exp. Mar. Biol. Ecol. 501, 54-64. https://doi.org/10.1016/j.jembe.2018.01.002.

Gonçalves, C., Santos, C., Bairrinho, E., Ferreira, H., 2011. Plano de Gestão das Bacias Hidrográficas do Vouga, Mondego e Lis. PARTE A - Avaliação Ambiental | Relatório Ambiental. 2011_10_AAE_RA_GEO, 214 (last accessed March 2020).

Halpern, B.S., Frazier, M., Potapenko, J., Casey, K.S., Koenig, K., Longo, C., Lowndes, J.S., Rockwood, R.C., Selig, E.R., Selkoe, K.A., Walbridge, S., 2015. Spatial and temporal changes in cumulative human impacts on the world's ocean. Nat. Commun. 6 (7615), 1-7. https://doi.org/10.1038/ncomms8615.

Hammer, Ø., Harper, D.A.T., Ryan, P.D., 2001. PAST: Paleontological Statistics Software Package for Education and Data Analysis. Palaeontol. Electronica 4 (1), 9-18. https://folk.uio.no/ohammer/past/.

Hughes, R.G., Paramor, O.A.L., 2004. On the loss of saltmarshes in south-east England and methods for their restoration. J. Appl. Ecol. 41, 440-448. https://doi.org/10. 1111/j.0021-8901.2004.00915.x.

ICRLC, 1987. Guidance on the Assessment and Redevelopment of Contaminated Land. Guidance Note 59/83. Department. of Environment, London.

Islam, S., Haque, M., 2004. The mangrove-based coastal and nearshore fisheries of Bangladesh: ecology, exploitation and management. Rev. Fish Biol. Fish. 14 (2), 153-180. https://doi.org/10.1007/s11160-004-3769-8.

IPCC, Intergovernmental Panel on Climate Change., 2018: Summary for Policymakers. In: Global warming of $1.5^{\circ} \mathrm{C}$. An IPCC Special Report on the impacts of global warming of $1.5^{\circ} \mathrm{C}$ above pre-industrial levels and related global greenhouse gas emission pathways, in the context of strengthening the global response to the threat of climate change, sustainable development, and efforts to eradicate poverty [V. MassonDelmotte, P. Zhai, H. O. Pörtner, D. Roberts, J. Skea, P. R. Shukla, A. Pirani, W. Moufouma-Okia, C. Péan, R. Pidcock, S. Connors, J. B. R. Matthews, Y. Chen, X. Zhou, M. I. Gomis, E. Lonnoy, T. Maycock, M. Tignor, T. Waterfield (eds.)]. World Meteorological Organization, Geneva, Switzerland, 32 pp.

Jørgensen, S.E., Marques, J., Nielsen, S.N., 2002. Structural changes in an estuary, described by models and using exergy as an orientor. Ecological Modeling 158,
233-240.

Kenov, I.A., Garcia, A.C., Neves, R., 2012. Residence time of water in the Mondego Estuary (Portugal). Estuar. Coast. Shelf Sci. 106, 13-22. https://doi.org/10.1016/j. ecss.2012.04.008.

Kriebel, D., Tickner, J., Epstein, P., Lemons, J., Levins, J., Loechler, E.L., Quinn, M. Rudel, R., Schettler, T., Stoto, M., 2001. The Precautionary Principle in Environmental Science. Environ. Health Perspect. 109, 871-876. https://doi.org/10. 1289/ehp.01109871.

Leo, K.L., Gillies, C.L., Fitzsimons, J.A., Hale, L.Z., Beck, M.W., 2019. Coastal habitat squeeze: A review of adaptation solutions for saltmarsh, mangrove and beach habitats. Ocean Coast. Manag. 175, 180-190. https://doi.org/10.1016/j.ocecoaman. 2019.03.019.

Levrel, H., Cabral, P., Marcone, O., Mongruel, R., 2014. The services provided by marine ecosystems. In: Monaco, A., Prouzet, P. (Eds.), Value and Economy of Marine Resources. John Wiley \& Sons Inc, USA, pp. 1-51.

Lillebø, A.I., Flindt, M.R., Pardal, M.A., Marques, J.C., 1999. The effect of macrofauna, meiofauna and microfauna on the degradation of Spartina maritima detritus from a salt marsh area. Acta Oecologica 20, 249-258. https://doi.org/10.1007/s10750-0060535-z.

Lillebø, A.I., Neto, J.M., Martins, I., Verdelhos, T., Leston, S., Cardoso, P.G., Ferreira, S.M., Marques, J.C., Pardal, M.A., 2005. Management of a shallow temperate estuary to control eutrophication: the effect of hydrodynamics on the system nutrient loading. Estuar. Coast. Shelf Sci. 65, 697-707. https://doi.org/10.1016/j.ecss.2005. 07.009.

Liu, Z., Xiu, C., Song, W., 2019. Landscape-Based Assessment of Urban Resilience and Its Evolution: A Case Study of the Central City of Shenyang. Sustainability 11, 2964. https://doi.org/10.3390/su11102964.

Loureiro, J., Castro, P., Alves, F., Figueiredo, A. (Coord.) 2017. Plano Intermunicipal de Adaptação às Alterações Climáticas (PIAAC) da CIM-REGIÃO DE COIMBRA.

Mantas, V.M., Pereira, A.J.S.C., Neto, J., Patrício, J., Marques, J.C., 2013. Monitoring estuarine water quality using satellite imagery. The Mondego river estuary (Portugal) as a case study. Ocean Coast. Manag. 72, 13-21. https://doi.org/10.1016/j ocecoaman.2011.06.013.

Mantas, V.M., Marques, J.C., Pereira, A.J.S.C., 2016. A geospatial approach to monitoring impervious surfaces in watersheds using Landsat data (the Mondego Basin, Portugal as a case study). Ecol. Ind. 71, 449-466. https://doi.org/10.1016/j.ecolind.2016.07. 013.

Marques, J.C., Maranhão, P., Pardal, M.A., 1993. Human impact on the subtidal macrobenthic community structure in the Mondego estuary (western Portugal). Estuar. Coast. Shelf Sci. 37, 403-419.

Marques, J.C., Neto, J.M., Patrício, J., Pinto, R., Teixeira, H., Veríssimo, H., 2007 Monitoring the Mondego estuary. Anthropogenic changes and their impact on ecological quality. Preliminary results from the first assessment of the effects of the reopening the communication between north and south arms on the eutrophication state of the system. Final Report, January 2007, IMAR/INAG, 87 pp.

Martins, I., Marques, J.C., Jørgensen, S.E., Nielsen, S.N., 1997. Modelling the effects of macroalgae blooms on the population dynamics of Cyathura carinata (Crustacea: Isopoda) in a eutrophied estuary. Ecol. Model. 102, 33-53.

Martins, I., Pardal, M.A., Lillebø, A.I., Flindt, M.R., Marques, J.C., 2001. Hydrodynamics as a major factor controlling the occurrence of green macroalgal blooms in a eutrophic estuary: a case study on the influence of precipitation and river management. Estuar. Coast. Shelf Sci. 52, 165-177.

MEA, Millennium Ecosystem Assessment, 2005. Ecosystems and Human Well-being Synthesis. Ecosystems Vol, 5). https://doi.org/10.1196/annals.1439.003.

Mishra, S., Sarkar, U., Taraphder, S., Datta, S., Swain, D., Saikhom, R., Panda, S. Laishram, M., 2017. Principal component analysis. International Journal of Livestock Research 7 (5), 60-78. https://doi.org/10.5455/ijlr.20170415115235.

MSFD; EC, 2008. Directive of the European Parliament and the Council 2008/56/EC Establishing a Framework for Community Action in the Field of Marine Environmental Policy (Marine Strategy Framework Directive). Official Journal of the European Union 64:19-40.

Munns, W.R. Jr, Rea, A.W., Suter, G.W. II, Martin, L., Blake-Hedges, L., Crk, T., Davis, C., Ferreira, G., Jordan, S., Mahoney, M., Barron, M.G., 2015. Ecosystem services as assessment endpoints for ecological risk assessment. Integrated Environmental Assessment and Management - Volume 12, Number 3-pp. 522-528. https://doi. org/10.1002/ieam.1707.

Muñoz, M., Reul, A., Gil de Sola, L., Lauerburg, R.A.M., Tello, O., Gimpel, A., Stelzenmuller, V., 2018. A spatial risk approach towards integrated marine spatial planning: A case study on European hake nursery areas in the North Alboran Sea. Marine Environmental Research 142, 190-207. https://doi.org/10.1016/j. marenvres.2018.10.008.

Neto, J.M., Flindt, M.R., Marques, J.C., Pardal, M.A., 2008. Modelling nutrient mass balance in a temperate macro-tidal estuary: implications to management. Estuar. Coast. Shelf Sci. 76, 175-185. https://doi.org/10.1016/j.ecss.2007.06.013.

Neto, J.M., Teixeira, H., Patrício, J., Baeta, A., Veríssimo, H., Pinto, R., Marques, J.C., 2010. The response of estuarine macrobenthic communities to natural- and humaninduced changes: dynamics and ecological quality. Estuaries Coasts 33, 1327-1339.

Neto, J.M., Barroso, D.V., Barría, P., 2013. Seagrass Quality Index (SQI), a Water Framework Directive compliant tool for the assessment of transitional and coastal intertidal areas. Ecol. Ind. 30, 130-137. https://doi.org/10.1016/j.ecolind.2013.02. 015

Parravicini, V., Rovere, A., Vassallo, P., Micheli, F., Montefalcone, M., Morri, C., Paoli, C., Albertelli, G., Fabiano, M., Bianchi, C.N., 2012. Understanding relationships between conflicting human uses and coastal ecosystems status: a geospatial modeling approach. Ecol. Ind. 19, 253-263. https://doi.org/10.1016/j.ecolind.2011.07.027.

Pereira, P., Vale, C., Ferreira, A.M., Pereira, E., Pardal, M.A., Marques, J.C., 2007. 
Seasonal variation of surface sediments composition in Mondego river estuary. Journal of Environmental Science and Health, Part A 40, 317-329. https://doi.org/ 10.1081/ESE-200045539.

Pereira, D.G., Afonso, A., Medeiros, F.M., 2015. Overview of Friedman's Test and Post-hoc Analysis. Communications in Statistics - Simulation and Computation 44 (10), 2636-2653. https://doi.org/10.1080/03610918.2014.931971.

Pinto, R., de Jonge, V.N., Neto, J.M., Domingos, T., Marques, J.C., Patrício, J., 2013a. Towards a DPSIR driven integration of ecological value, water uses and ecosystem services for estuarine systems. Ocean Coast. Manag. 72, 64-79. https://doi.org/10 1016/j.ocecoaman.2011.06.016.

Pinto, R., de Jonge, V.N., Chainho, P., Costa, J.L., Marques, J.C., Patrício, J., 2013b. Temporal stability in estuarine systems: implications for ecosystem services provision. Ecol. Ind. 24, 246-253. https://doi.org/10.1016/j.ecolind.2012.06.022.

Pinto, R., de Jonge, V.N., Marques, J.C., 2014. Linking biodiversity indicators, ecosystem functioning, provision of services and human well-being in estuarine systems: application of a conceptual framework. Ecol. Ind. 36, 644-655. https://doi.org/10. 1016/j.ecolind.2013.09.015.

Rao, N.S., Ghermandi, A., Portela, R., Wang, X., 2015. Global values of coastal ecosystem services: a spatial economic analysis of shoreline protection values. Ecosyst. Serv. 11, 95-105. https://doi.org/10.1016/j.ecoser.2014.11.011.

Raposa, K.B., Wasson, K., Smith, E., Crooks, J.A., Delgado, P., Fernald, S.H., Ferner, M.C., Helms, A., Hice, L.A., Mora, J.W., Puckett, B., Sanger, D., Shull, S., Spurrier, L., Stevens, R., Lerberg, S., 2016. Assessing Tidal Marsh Resilience to Sea-Level Rise at Broad Geographic Scales with Multimetric Indices. Biol. Conserv. 204, 263-275. https://doi.org/10.1016/j.biocon.2016.10.015.

Rhodes, C., Bingham, A., Heard, A.M., Hewitt, J., Lynch, J., Waite, R., Bell, M.D., 2017. Diatoms to human uses: linking nitrogen deposition, aquatic eutrophication, and ecosystem services. Ecosphere 8 (7), e01858.

Rodríguez-Loinaz, G., Alday, J.G., Onaindia, M., 2014. Multiple ecosystem services landscape index: A tool for multifunctional landscapes conservation. J. Environ. Manage. 147, 152-163. https://doi.org/10.1016/j.jenvman.2014.09.001.

Rova, S., Pastres, R., Zucchetta, M., Pranovi, F., 2018. Ecosystem services' mapping in data-poor coastal areas: which are the monitoring priorities? Ocean Coast. Manag. https://doi.org/10.1016/j.ocecoaman.2017.11.021.

Sampath, D.M.R., Boski, T., 2016. Morphological response of the saltmarsh habitats of the Guadiana estuary due to flow regulation and sea-level rise. Estuarine, Coastal and Shelf Science, 183(Part B), 314-326. https://doi.org/10.1016/j.ecss.2016.07.009.

Samper-Villarreal, J., Lovelock, C.E., Saunders, M.I., Roelfsema, C., Mumby, P.J., 2016. Organic carbon in seagrass sediments is influenced by seagrass canopy complexity, turbidity, wave height, and water depth. Limnol. Oceanogr. 61, 938-952. https://doi. org/10.1002/lno.10262.

Sandi, S.G., Rodríguez, J.F., Saintilan, N., Riccardi, G., Saco, P.M., 2018. Rising tides, rising gates: The complex ecogeomorphic response of coastal wetlands to sea-level rise and human interventions. Adv. Water Resour. 114, 135-148. https://doi.org/10. 1016/j.advwatres.2018.02.006.

Santos, C. F., Andrade, F., 2009. Environmental sensitivity of the Portuguese coast in the scope of oil spill events-comparing different assessment approaches. Journal of Coastal Research, Spec. Issue 56, 885-889. www.jstor.org/stable/25737706.

Santos, L.I.V., do Carmo, J.S.A., Pinho, J.L.S.,, 2012. Influence of the sea level rise on the river Mondego estuary. Portugal. Revista Recursos Hídricos. 33 (1). https://doi.org/ 10.5894/rh33n1-1.

Schoutens, K., Heuner, M., Minden, V., Ostermann, T.S., Silinski, A., Belliard, J.P., Temmerman, S., 2019. How effective are tidal marshes as nature-based shoreline protection throughout seasons? Limnol. Oceanogr. 64, 1750-1762. https://doi.org/ 10.1002/lno.11149.

Sharp, R., Tallis, H.T., Ricketts, T., Guerry, A.D., Wood, S.A., Chaplin-Kramer, R., Nelson, E., Ennaanay, D., Wolny, S., Olwero, N., Vigerstol, K., Pennington, D., Mendoza, G., Aukema, J., Foster, J., Forrest, J., Cameron, D., Arkema, K., Lonsdorf, E., Kennedy, C., Verutes, G., Kim, C.K., Guannel, G., Papenfus, M., Toft, J., Marsik, M., Bernhardt, J., Griffin, R., Glowinski, K., Chaumont, N., Perelman, A., Lacayo, M. Mandle, L., Hamel, P., Vogl, A.L., Rogers, L., Bierbower, W., Denu, D., and Douglass, J., 2018. InVEST 3. 7.0. post17 + ug.hbeb7e1912b14 User's Guide. The Natural Capital Project, Stanford University, University of Minnesota, The Nature Conservancy, and World Wildlife Fund.

Short, F.T., Kosten, S., Morgan, P.A., Malone, S., Moore, G.E., 2016. Impacts of climate change on submerged and emergent wetland plants. Aquat. Bot. 135, 3-17. https:// doi.org/10.1016/j.aquabot.2016.06.006.

Schröter, D., Cramer, W., Leemans, R., Prentice, I. C., Araújo, M.B., Arnell, N.W., Bondeau, A., Bugmann, H., Carter, T.R., Gracia, C.A., de la Veja-Leinert, A.C., Erhard, F.E., Glendining, M., House, J.I., Kankaanpää, Klein, R.J.T., Lavorel, S.,Lindner,M., Metzger,M.J., Meyer, J., Mitchell, T.D., Reginster, I., Rounsevell, M., Sabaté, S., Sitch, S., Smith, B., Smith, J., Smith, P., Sykes, M.T., Thonicke, K., Thuiller, W., Tuck, G., Zaehle, S., Ziert., B., 2005. Ecosystem service supply and vulnerability to global change in Europe. Science, 310, 1333-1337. https://doi.org/10.1126/science. 1115233.

Singh, G.G., Sinner, J., Ellis, J., Kandlikar, M., Halpern, B.S., Satterfield, T., Chan, K.M.A., 2017. Mechanisms and risk of cumulative impacts to coastal ecosystem services: An expert elicitation approach. J. Environ. Manage. 199, 229-241. https://doi.org/10. 1016/j.jenvman.2017.05.032.

Sousa, A.I., Lillebø, A.I., Caçador, I., Pardal, M.A., 2008. Contribution of Spartina maritima to the reduction of eutrophication in estuarine systems. Environ. Pollut. 156, 628-635. https://doi.org/10.1016/j.envpol.2008.06.022.
Sousa, A.I., Santos, D.B., Da Silva, E.F., Sousa, L.P., Cleary, D.F., Soares, A.M., Lillebø, A.I., 2017. 'Blue Carbon and Nutrient Stocks of Salt Marshes at a Temperate Coastal Lagoon (Ria de Aveiro, Portugal). Sci. Rep. 7, 41225. https://doi.org/10.1038/ srep 41225 .

Syrbe, R.-U., Grunewald, K., 2017. Ecosystem service supply and demand - the challenge to balance spatial mismatches. International Journal of Biodiversity Science, Ecosystem Services \& Management 13 (2), 148-161. https://doi.org/10.1080/ 21513732.2017.1407362.

Teck, S.J., Halpern, B.S., Kappel, C.V., Micheli, F., Selkoe, K.A., Crain, C.M., Martone, R., Shearer, C., Arvai, J., Fischhoff, B., Murray, G., Neslo, R., Cooke, R., 2010. Using expert judgment to estimate marine ecosystem vulnerability in the California Current. Ecol. Appl. 20 (5), 1402-1416. https://doi.org/10.1890/09-1173.1.

Teixeira, H., Salas, F., Pardal, M.A., Marques, J.C., 2007. Applicability of ecological evaluation tools in estuarine ecosystems: the case of the lower Mondego estuary (Portugal). Hydrobiologia 587, 101-112. https://doi.org/10.1007/s10750-0070697-3.

Teixeira, H., Salas, F., Borja, A., Neto, J.M., Marques, J.C., 2008. A benthic perspective in assessing the ecological status of estuaries: the case of the Mondego estuary (Portugal). Ecol. Ind. 8, 404-416. https://doi.org/10.1016/j.ecolind.2007.02.008.

Teixeira, Z., Teixeira, H., Marques, J.C., 2014. Systematic processes of land use/land cover change to identify relevant driving forces: implications on water quality. Sci. Total Environ. 470-471, 1320-1335. https://doi.org/10.1016/j.scitotenv.2013.10. 098.

Teixeira, Z., Marques, J.C., 2016. Relating landscape to stream nitrate-N levels in a coastal eastern-Atlantic watershed (Portugal). Ecol. Ind. 61 (1), 693-706. https://doi. org/10.1016/j.ecolind.2015.10.021.

Teixeira, Z., Marques, C., Mota, J.S., Garcia, A.C., 2018. Identification of potential aquaculture sites in solar saltscapes via the Analytic Hierarchy Process. Ecol. Ind. 93, 231-242. https://doi.org/10.1016/j.ecolind.2018.05.003.

Vale, C., Ferreira, A., Caetano, M., Brito, P., 2002. Elemental composition and contaminants in surface sediments of the Mondego river estuary. In: Pardal, M.A., Marques, J.C., Graça, M.A. (Eds.), Aquatic Ecology of the Mondego River Basin. Global Importance of Local Experience. Imprensa da Universidade de Coimbra, Coimbra, pp. 243-256.

Van der Linden P, Marchini A, Dolbeth M, Patrício J, Veríssimo H, Marques JC., 2016. The performance of trait-based indices in an estuarine environment. Ecological Indicators; Ecological Indicators 61, 378-389 https://doi.org/10.1016/j.ecolind. 2015.09.039.

Vasconcelos, R.P., Reis-Santos, P., Fonseca, V., Maia, A., Ruano, M., França, S., Vinagre, C., Costa, M.J., Cabral, H., 2007. Assessing anthropogenic pressures on estuarine fish nurseries along the Portuguese coast: A multi-metric index and conceptual approach. Sci. Total Environ. 374, 199-215. https://doi.org/10.1016/j.scitotenv.2006.12.048.

Veríssimo, H., Patrício, J., Teixeira, H., Carriço, A., Marques, J.C., 2013a. Testing different ecological scenarios in a temperate estuary: a contribution towards the implementation of the Ecological Potential assessment. Mar. Pollut. Bull. 71, 168-178. https://doi.org/10.1016/j.marpolbul.2013.03.019.

Veríssimo, H., Lane, M., Patrício, J., Gamito, S., Marques, J.C., 2013b. Trends in water quality and subtidal benthic communities in a temperate estuary: is the response to restoration efforts hidden by climate variability and the estuarine quality paradox? Ecol. Ind. 24, 56-67. https://doi.org/10.1016/j.ecolind.2012.05.028.

Veríssimo, H., Verdelhos, T., Baeta, A., Linden, P.V.D., Garcia, A.C., Marques, J.C., 2017. Comparison of thermodynamic-oriented indicators and trait-based indices ability to track environmental changes: Response of benthic macroinvertebrates to management in a temperate estuary. Ecol. Ind. 73, 809-824. https://doi.org/10.1016/j. ecolind.2016.10.040.

Villamagna, A.M., Angermeier, P.L., Bennett, E.M., 2013. Capacity, pressure, demand, and flow: A conceptual framework for analyzing ecosystem service provision and delivery. Ecol. Complexity 15, 114-121. https://doi.org/10.1016/j.ecocom.2013.07. 004.

Walker, B., Holling, C., Carpenter, S.R., Kinzig, A., 2004. Resilience, adaptability and transformability in social-Ecological systems. Ecology and Society [online]. 9 (2), 5. http://www.ecologyandsociety.org/vol9/iss2/art5.

Waycott, M., Duarte, C.M., Carruthers, T.J.B., Orth, R.J., Dennison, W.C., Olyarnik, S., Calladine, A., Fourqurean, J.W., Heck, K.L., Hughes, A.R., Kendrick, G.A., Kenworthy, W.J., Short, F.T., Williams, S.L., 2009. Accelerating loss of seagrassesacross the globe threatens coastal ecosystems. Proc. Natl. Acad. Sci. 106, 12377-12381. https://doi.org/10.1073/pnas.0905620106.

WFD; EC, 2000. Directive of the European Parliament and of the Council of 23 October 2000 establishing a framework for Community action in the field of water policy (Water Framework Directive) https://eur-lex.europa.eu/legal-content/EN/TXT/ ?uri = CELEX:32000L0060.

Willaert, T., García-Alegre, A., Queiroga, H., Cunha-e-Sá, M.A., Lillebø, A.I., 2019. Measuring Vulnerability of Marine and Coastal Habitats' Potential to Deliver Ecosystem Services: Complex Atlantic Region as Case Study. Front. Mar. Sci. 6, 199. https://doi.org/10.3389/fmars.2019.00199.

Wyatt, K.H., Griffin, R., Guerry, A.D., Ruckelshaus, M., Fogarty, M., Arkema, K.K., 2017. Habitat risk assessment for regional ocean planning in the U.S. Northeast and MidAtlantic. PLoS One 12 (12), e0188776. https://doi.org/10.1371/journal.pone. 0188776.

Zimmerman, D.W., Zumbo, B.D., 1993. Relative Power of the Wilcoxon Test, the Friedman Test, and Repeated-Measures ANOVA on Ranks. J. Exp. Educ. 62 (1), 75-86. https://doi.org/10.1080/00220973.1993.9943832. 